\title{
Exploring the nonlinear effect of conditional conservatism on the cost of equity capital: Evidence from emerging markets
}

\author{
Maha Khalifa \\ Associate Professor of Accounting \\ Faculté des Sciences Juridiques, Economique et de Gestion de Jendouba \\ University of Jendouba, Tunisia \\ LIGUE-ISCAE, University of Manouba, Tunisia \\ Email: khalifa maha86@yahoo.fr \\ Haykel Zouaoui \\ Associate Professor of Statistics \\ Institut Supérieur de Commerce et de Comptabilité de Bizerte \\ University of Carthage, Tunis, Tunisia \\ Email : zouaoui haykel@yahoo.fr \\ Hakim Ben Othman \\ Full Professor, Department of Accounting, \\ College of Business Administration, Prince Sultan University, \\ Phone: 966114948335 / Mobile +966 504969658 \\ Email: hbenothman@psu.edu.sa \\ Khaled Hussainey* \\ Full Professor of Accounting and Financial Management \\ Portsmouth Business School \\ University of Portsmouth \\ Room 6.22 Richmond Building, \\ Portland Street \\ Portsmouth, PO1 3DE \\ United Kingdom \\ Email: khaled.hussainey@port.ac.uk
}

$\left.{ }^{*}\right)$ corresponding author 


\begin{abstract}
In this study, we investigate the relationship between accounting conservatism and the cost of equity capital. Previous empirical studies examining this association use linear models that collectively resulted in a variety of contradictory outcomes. By combining existing theories in a new non-linear setting, we investigate the presence of a non-monotonic relationship between conservatism and the cost of equity capital for an international sample of public firms in 37 emerging countries during the period 2003-2012. Our findings present robust evidence suggesting a U-shaped, nonlinear relationship between accounting conservatism and the cost of equity capital. The same result holds for disaggregate measures of conservatism and other estimations techniques. The findings of this paper are in line with the theoretical framework of a "too-little-of-a-good-thing" effect, which indicates that the type of the association (negative or positive) depends on the level of conservatism. That is, the relationship is negative to an optimal point after which increasing the level of conservatism will increase the cost of equity capital. This paper sheds more light on the conservatism-cost of equity capital nexus and provides managers, investors, and policymakers with evidence to what extent conservatism is considered as beneficial or harmful.
\end{abstract}

Keywords: Conditional conservatism; the cost of equity capital; nonlinear; U-shape; emerging countries.

JEL Classification: G10, G15, G30, G32, M41, M48. 


\section{Introduction}

There is an ongoing debate between academics and standard-setters on to what extent conservatism is considered as beneficial or harmful for the users of financial statements. The Financial Accounting Standards Board (FASB) and International Accounting Standards Board (IASB) no longer consider accounting conservatism as a desirable qualitative attribute of financial reporting because they believe conservatism may induce a negative bias into financial statements and alters neutrality (FASB, 2010, Ruch \& Taylor, 2015). In response to this changed position of the FASB and IASB regarding accounting conservatism, a growing body of studies examines the economic consequences of accounting conservatism, specifically, how accounting conservatism affects the cost of equity capital.

Theory offers ambiguous predictions about the effect of conservatism on the cost of equity capital. The first strand of analytical research predicts that accounting conservatism reduces the cost of equity capital by decreasing information risk, decreasing information asymmetry, and limiting earnings management. Researchers within this framework argue that conservatism practices enhance the quality of information environment by increasing information efficiency, increasing information precision (Ball, 2001; Bagnoli \& Watts, 2005; Gietzmann \& Trombetta, 2003; Fan \& Zhang, 2011; Lafond \& Watts, 2008; Suijs, 2008; Hu et al.,2014), curbing opportunities for earnings management (Watts, 2003; Guay \& Verrecchia, 2006; Chen et al., 2007; Lafond \& Watts, 2008), fostering comprehensive disclosure via the development of information sources other than financial statements to convey information about expected gains (Guay \& Verrecchia, 2018), and limiting false signaling by bad firms (Nan \& Wen, 2011). Accordingly, accounting conservatism reduces overall information risk and, therefore, the cost of equity capital.

In contrast, other researchers support the existence of a positive relationship between accounting conservatism and the cost of equity capital. Some theoretical studies argue that enhancing overall information quality may increase information asymmetry and in turn the cost of equity capital, especially in imperfect markets (Gowet al., 2011; Lambert et al., 2011). In addition, conservatism practices may be subject to opportunistic behavior from management via "big bath" accounting, which may compromise earnings quality and increase the cost of equity capital (Chan et al., 2009). Gigler et al. (2009) argue that financial reports with more frequent bad news disclosures would have lower information content, which reduces earnings quality. In the same vein, other researchers provide evidence that conservatism practices impair 
information quality for analysts and yields biased, scrambled, and inefficient earnings forecasts (Mensah et al., 2004; Helbok \& Walker, 2004; Pae \& Thornton, 2010; FASB, 2010; Louis et al., 2014). Johnstone (2016) analytically demonstrates that timely loss recognition (conservatism) may increase the cost of equity financing by lowering expected payoffs, even in cases where information has great precision.

The existing empirical studies on the effect of accounting conservatism on the cost of equity capital provide mixed (positive or negative) and inconclusive results. For instance, Francis et al. (2004) did not find a significant relationship between accounting conservatism and the cost of equity capital. However, Chan et al. (2009) and Biddle et al. (2012) find a positive association between conditional conservatism and the cost of equity capital. In contrast to them, other studies provide empirical evidence of a negative association between conservatism and the cost of equity capital (Artiach \& Clarkson, 2014; Garcia et al., 2011; Khalifa \& Ben Othman, 2015; Li, 2015; Khalifa et al., 2018).

Ruch and Taylor (2015) argue that mixed results are due to measurement issues of the cost of equity capital and accounting conservatism. However, our prediction is that mitigated findings are likely attributable to the use of linear models, which can fail in modeling the existence of competing theories (Pierce \& Aguinis, 2013; Guenther \& Hoppe, 2014). Therefore, we hypothesize that the relationship between accounting conservatism and the cost of equity capital may be nonlinear. This hypothesis is developed by the theoretical settings that incorporate the possibility of negative, positive, or neutral association between accounting conservatism and the cost of equity capital. Our prediction finds its roots in two theoretical frameworks that are used to combine conflicting theories. The first is the meta-theory of the too-much-of-a-good-thing (TMGT) effect (Pierce \& Aguinis, 2013). The TMGT effect assumes that each relationship between two variables reaches a certain maximum after which a further increase in the predictive variable leads to a decrease in the response variable. In other words, the TMGT effect integrates positive and negative associations in one framework that predicts an inverted U-shaped relationship. The second is “too-little-of-a-good-thing' (TLGT) theory (Trumpp \& Guenther, 2015). In contrast to the TMGT effect, the TLGT theory assumes a Ushaped association where the relationship starts with a negative effect until a threshold, after which it turns to positive.

The existence of the potential TMGT or TLGT effects between accounting conservatism and the cost of equity capital raises serious concerns about the accuracy of linear models used 
in previous empirical studies. Therefore, our paper intends to shed more light on the type of the relationship between accounting conservatism and the cost of equity capital by answering the following research question: Is there empirical evidence of a non-linear association between accounting conservatism and the cost of equity capital?

We conduct empirical investigations on the association between accounting conservatism and the cost of equity capital by using the Khan and Watts (2009) firm-year measure of conditional conservatism and the Estrada (2000, 2001, 2004, and 2007) downside risk-based measure of the cost of equity capital. Based on an international sample of public firms in 37 emerging countries during the period 2003-2012, we employ pooled ordinary least squares (OLS) regression to estimate the relationship between accounting conservatism and the cost of equity capital.

As predicted, the empirical results suggest a U-shaped, nonlinear relationship between accounting conservatism and the cost of equity capital. Our findings support the theoretical framework of TLGT effect, which indicates that the type of relationship (negative or positive) depends on the level of conditional conservatism. That is, conditional conservatism reduces the cost of equity capital to a threshold point after which increasing levels of accounting conservatism leads to a higher cost of equity capital. Our results show that the nonlinear relationship remains stable when using desegregate measures of conditional conservatism, and even after using different estimation strategies including fixed effects, random effects, quantile regression, and piecewise linear regression.

Our study makes several contributions. First, this paper enriches the growing body of research on the economic consequences of accounting conservatism in equity markets, especially its effect on the cost of equity capital. Second, to the best of our knowledge, this study is the first that models and examines the existence of a nonlinear relationship between accounting conservatism and the cost of equity capital. Third, contrary to previous studies that use data sample from developed countries, our study focuses on public firms in emerging countries. Emerging countries have gained more importance in international markets and have become places with higher growth opportunities. In addition, a free circulation of capital and the liberalization of trade provide international equity investors, companies, and financial institutions with opportunities to diversify their equity portfolio. Moreover, emerging countries are characterized by lower institutional quality index (i.e., political stability, rule of law, regulatory quality, control of corruption, voice and accountability, and effectiveness in 
governance) comparing to developed countries (LaPorta et al., 1998). Therefore, examining the relationship between accounting conservatism and the cost of equity capital in such a setting could lead to different results.

Our findings are of potential interest for managers, regulatory bodies, and international equity investors. For managers wanting to reduce their financial costs in the capital markets, accounting conservatism may be used as a strategic accounting practice to communicate accounting information with higher value relevance and consequently provide financial statements with improved quality. However, managers should be aware of the existence of a potential threshold after which conservatism practice may lead to an increase in the information risk, and hence in the cost of equity capital. Therefore, firms should calibrate their level of conditional conservatism in order to maximize the benefits of this practice in equity markets.

At a regulatory level, standard setters need to pay more careful attention to accounting conservatism and its information role. In some circumstances, our evidence stands in opposition to the FASB's claim that accounting conservatism goes against the neutrality feature of financial statements and conservatism elimination from the conceptual framework. On the other hand, our evidence supports that claim when excessive conservatism is practiced. Accordingly, standard setters should develop accounting standards that make a trade-off between the neutrality principle and accounting conservatism. Equity investors, as providers of capital and users of financial statements, want to receive more precise financial information about actual and future earnings in order to reduce information asymmetry and decrease their risk of poor firm value estimations. Our study provides evidence that this can be reached through accounting conservatism up to an optimal point after which investors could consider that higher levels of conservatism may curb the dissemination of new information and consequently increase the information asymmetry and reduce the quality of financial reporting.

The rest of this paper is organized as follows: Section 2 reviews the theoretical and empirical studies before developing the research hypotheses. Section 3 presents the research methodology. Sections 4 and 5 present the results and the additional tests. Section 6 concludes.

\section{Literature review and hypotheses development}

2.1. Conditional conservatism and the cost of equity capital: The theoretical framework

The theoretical and empirical studies on the cost of equity capital have thoroughly examined the factors that influence it. In the financial accounting research area, a large body of 
studies examined the effect of different aspects of earnings quality on the cost of equity capital (Easley \& O’hara, 2004; Francis et al., 2004; Francis et al., 2005; Aboody et al., 2005; Chan et al., 2009; Chang et al., 2009; McInnis, 2010; Kim \& Sohn, 2013; Artiach \& Clarkson, 2014; Khalifa \& Ben Othman, 2015; Li, 2015; Khalifa et al., 2018). There is a consensus among these studies that firms with less earnings quality have a higher cost of equity capital.

One of the most influential attributes of earnings quality is accounting conservatism (Watts \& Zimmerman, 1986; Basu, 1997; Watts, 2003). However, the theory offers opposite predictions regarding the effect of accounting conservatism on the cost of equity capital. The first stream of research predicts that there is a negative association between conservatism and the cost of equity capital. For example, Gietzmann and Trombetta (2003) develop an analytical model within which managers are holding private information with respect to the expected future earnings and can choose either voluntary disclosure or conservative accounting practices as quality signals. They demonstrate that accounting conservatism can act as a substitute for voluntary disclosure allowing managers to signal private information about future earnings. As voluntary disclosure reduces the firm's cost of equity capital by reducing non-diversifiable information risk (Diamond \& Verrecchia, 1981; Botoson, 1997; Botosan \& Plumlee, 2002; Francis et al., 2004; Botosan, 2006), accounting conservatism could decrease the cost of equity capital.

Consistent with Gietzmann and Trombetta (2003), Bagnoli and Watts (2005) construct a signaling model and demonstrate the commitment of managers to produce conservative accounting numbers allows investors to infer private information about firms' future prospects. Therefore, with more gained information, investors are able to assess the firm value and hence reduce their estimation risk; thereby decreasing their required return rate.

Guay and Verrecchia (2007) and Suijs (2008) argue that the choice of reporting conservatively could affect the firm's value and consequently its cost of equity capital. For instance, Guay and Verrecchia (2006) attest that managers tend to proceed in a strategic manner and divulge only positive expectations about firm's market value, delay the recognition of difficult-to-verify losses, and withhold information about negative expectations regarding future cash flows. They develop an analytical framework within which outside investors anticipate strategic disclosure and apply a discount in cases where managers withhold information. Through their model, they demonstrate that when there is a regulatory enforcement of accounting conservatism, full disclosure is achieved. That is, negative incomes are disclosed 
through income statements and positive incomes are disclosed on a timely basis through other communication channels. In such cases, outsider investors get information on both negative and positive expected cash flows. As a result, information uncertainty is reduced and the precision to value a firm increases, which in turn reduces the market discount applied to the firm value. Consistent with this point of view, Lambert et al. (2007) demonstrate that when accounting information quality is improved, market participants will enhance the precision with which a firm's market value is estimated, leading to a reduction in the cost of equity capital.

In the same way, LaFond and Watts (2008) show that accounting conservatism acts as a governance mechanism that curbs earnings management and limits agency costs generated by a managerial overstatement of assets and income. Finally, Suijs (2008) constructs a model of overlapping generations of investors and demonstrates that accounting conservatism improves risk sharing among generations of investors and, therefore, reduces overall investment risk which allows a lower cost of equity capital.

While the above studies suggest that accounting conservatism reduces the cost of equity capital by enhancing overall information quality and precision, the second stream of theoretical studies predicts that accounting conservatism could increase the cost of equity capital. For instance, Gow et al. (2011) and Lambert et al. (2011) argue that more precise information may increase the heterogeneity of opinions between more and less sophisticated investors resulting in different levels of understanding, which in turn may increase asymmetry information. Indeed, market participants with informational advantage have more influence on stock prices and less sophisticated investors with information disadvantage thus require higher compensations to enter to the market. Consistent with this view, a large body of theoretical studies state that public disclosure can lead to less sophisticated investors increasing their demand for private information held by more sophisticated investors, which increases opinion divergence and information asymmetries among market participants (Kim \& Verrecchia, 1991; Demski \& Feltman, 1994; McNichols \& Trueman, 1994). This also increases the cost of equity capital, especially in less perfect and competitive markets (Armstrong et al., 2011; Gow et al, 2011; Akins et al., 2012). In the same vein, Biddle et al. (2016) argue that enhanced information quality generated by accounting conservatism can yield to a greater heterogeneity of opinions and generate new information asymmetry among market participants, as stock markets are more sensitive to negative earnings news. 
In addition, Johnstone (2016) argues that conditional conservatism conveys news about income-decreasing events and lower expected payoffs, and revealing bad news more precisely could increase the cost of equity capital. Other researchers also provide evidence that conservatism practices impair information quality for analysts and yields biased, scrambled, and inefficient earnings forecasts which in turn may decrease market firm values and increases the cost of equity capital (Mensah et al., 2004; Helbok \& Walker, 2004; Pae \& Thornton, 2010; FASB, 2010; Louis et al., 2014). This is consistent with the argument that FASB no longer considers accounting conservatism as a qualitative attribute of financial statements because it contradicts the neutrality principle and induces a negative downward bias in accounting numbers.

2.2. Conditional conservatism and the cost of equity capital: Empirical studies

Existing empirical studies on the relationship between conditional conservatism and the cost of equity capital report ambiguous (empirically insignificant) or contradictory results. For instance, Francis et al. (2004) examine the association between the cost of equity capital and seven earnings attributes: accrual quality, persistence, predictability, smoothness, value relevance, timeliness, and conservatism. Using the Basu (1997) asymmetric timeliness measure, they did not find a robust significant relationship between conditional conservatism and the cost of equity capital.

Garcia et al. (2011) examine the cost of equity capital implications of conditional conservatism for a sample of U.S. firms during the period 1976-2003. Unlike Francis et al, (2004), they use a firm-specific measure of conditional conservatism based on Callen et al. (2010) and a standard excess return model as in Fama and French (1992) to introduce risk factors, including beta, firm size, book-to-market, and momentum. They find, as predicted, robust evidence of a negative association between conditional conservatism and the cost of equity capital.

In the same vein, Artiach and Clarkson (2014) seek insight into the economic consequence of accounting conservatism by using 3,138 US firm-year observations from the period 1985-2000. They find, as expected, an inverse association between conditional conservatism and the cost of equity capital. Furthermore, they report that this relationship is more pronounced for firms with higher information asymmetry environment. 
In a related study, Khalifa and Ben Othman (2015) examine the effect of conditional conservatism on the cost of equity capital for a sample of 1,287 firm-year observations covering 12 countries from the Middle East and North Africa region during the period 2004-2007. Using a firm-specific measure of conditional conservatism based on Khan and Watts (2009) and the Estrada (2000) approach to measure the cost of equity capital, they find a negative relationship between conditional conservatism and the cost of equity capital.

$\mathrm{Li}$ (2015) examines the economic role of accounting conservatism on international debt and equity markets using a sample of 140,774 firm-year observations from 31 countries during the period 1991-2006 and based on the classical Basu (1997) model and ex ante measures of the cost of equity. She finds that firms from countries with a higher degree of conservatism are more likely to have a lower cost of debt and equity capital than firms in countries with lower levels of conservatism. Moreover, she reports that the negative association between conditional conservatism and the cost of equity is more pronounced in countries with higher investor protection.

In related literature, Hu et al. (2014) investigate how conditional conservatism improves firm information environment in 41 countries. Using the Basu (1997) model to measure the extent of conservatism, they find that accounting conservatism is positively associated with improved corporate information environments and argue that conservatism leads to a highquality information environment and reduces information asymmetry between insiders and outsiders. They also find that accounting conservatism can be considered as a substitute for legal institutions to ensure higher quality information environments.

However, several empirical studies find a positive association between accounting conservatism and the cost of equity capital. For example, using a sample of UK firms during the period 1987-1999, Chan et al. (2009) report that unconditional conservatism is associated with lower costs of equity and conditional conservatism is associated with a higher cost of equity capital. Investigating US public firms over the period 1986-2008, Biddle et al. (2012) document a positive association between conditional conservatism and the cost of equity capital. They argue that conditional conservatism lowers the quality of financial information by increasing information asymmetry, and as a consequence increases the firm's cost of equity capital.

2.3. Association between conservatism and the cost of equity capital: Hypotheses development 
As discussed above, the effect of accounting conservatism on the cost of equity capital finds its root in two competing theoretical arguments. These studies assume a uniformly positive or negative relationship between accounting conservatism and the cost of equity capital. Empirical studies offer mixed evidence. In sum, we predict that the association between conservatism and the cost of equity capital is more complex than to be simply considered as positive and negative. We also predict that the two effects (positive and negative) may coexist and combine in one theoretical framework that incorporates a trade-off and the possibility of both a negative and positive relationship between conservatism and the cost of equity capital. The resulting theoretical setting finds its origin in either the TMGT effect or the TLGT effect.

Pierce and Aguinis (2013) state that the TMGT effect ordinarily occurs when a set of predictor variables reach optimal points after which their relations with outcomes cease to be linear and positive. Because of this effect, there is a theoretical maximum after which an additional level of conditional conservatism lowers the cost of equity capital. The resulting function has an inverted U-shape. The second theory that can be used to account for mixed associations is the TLGT effect. The TLGT effect supposes a U-shaped association where the relationship starts with a negative effect before transforming into a positive one. Under the TLGT effect, there is a theoretically optimal point after which an additional level of conditional conservatism increases the cost of equity capital. Therefore, we develop the following research hypotheses:

\section{H1: The relationship between accounting conservatism and the cost of equity capital is non-linear.}

\section{H2: The relationship between accounting conservatism and the cost of equity capital follows a U-shaped curve.}

\section{Research design and data}

In this section, we describe variable measures, the regression model, and the sample selection.

\subsection{Conditional conservatism measures}


Conditional conservatism is defined as asymmetric timeliness in the recognition of gains versus losses in reported earnings. So under conservatism, losses are recognized in earnings more quickly than gains during the current period. Basu's (1997) model is the most used approach to assess the extent to which earnings reflect losses faster than gains (Wang et al., 2009). However, Basu's (1997) approach does not give a measure of conditional conservatism at the firm level. To overcome this drawback, Khan and Watts (2009) propose a new methodology to provide an estimate of conditional conservatism at firm level each year. Following Khan and Watts (2009), we specify the Basu (1997) model as follows:

$$
N I_{i t}=\beta_{0}+\beta_{1} D_{i t}+\beta_{2} R_{i t}+\beta_{3} D R_{i t}+\varepsilon_{i t}
$$

Where $N I$ it is the annual net income before extraordinary items of firm $\mathrm{t}$ in year $\mathrm{t}$, deflated by the market value of equity at the beginning of the period. $\mathrm{R}_{\mathrm{it}}$ is the annual return calculated as the sum of monthly returns. $\mathrm{D}$ is a dummy variable equal to 1 if $\mathrm{R}$ is negative (bad news) and 0 if $\mathrm{R}$ is positive (good news). The coefficient on $\mathrm{R}_{\mathrm{it}}\left(\beta_{2}\right)$ relates the timeliness of good news recognition while the coefficient on $\mathrm{DR}_{\text {it }}\left(\beta_{3}\right)$ reflects the asymmetric timeliness of earnings with respect to bad vs. good news (conditional conservatism).

To estimate the timeliness with which accounting reflects both good news and conditional conservatism at the firm-year level, Khan and Watts (2009) reformulate Basu (1997) model (equation (1)) by specifying both the incremental of bad news (referred to as CSCORE) each year and the timeliness of good news (referred to as GSCORE) each year as a linear functions of firm-specific characteristics each year as follows:

$$
\begin{aligned}
& \operatorname{CSCORE}_{i t}=\beta_{3}=\mu_{1}+\mu_{2} \operatorname{SIZE}_{i}+\mu_{3} M T B_{i}+\mu_{4} L E V_{i} \\
& \operatorname{GSCORE}_{i t}=\beta_{2}=\theta_{1}+\theta_{2} \operatorname{SIZE}_{i}+\theta_{3} M T B_{i}+\theta_{4} L E V_{i}
\end{aligned}
$$

Where SIZE is firm's size measured as the natural logarithm of the firm market value of equity, LEV is firms' leverage obtained as the ratio between total debt and market value of equity and MTB is the Market-to-Book ratio. CSCORE is the firm-year measure of conditional conservatism and GSCORE is the firm-year measure of timeliness of good news recognition.

To estimate CSCORE and GSCORE and following Khan and Watts (2009), we first substitute equations (2) and (3) into regression equation (1) to obtain the following annual crosssectional regression model: 


$$
\begin{aligned}
N I_{i}=\beta_{0}+\beta_{1} & D_{i t}+\left(\theta_{1}+\theta_{2} S_{I Z E_{i}}+\theta_{3} M T B_{i}+\theta_{4} L E V_{i}\right) R_{i t} \\
& +\left(\mu_{1}+\mu_{2} S I Z E_{i}+\mu_{3} M T B_{i}+\mu_{4} L E V_{i}\right) D R_{i t}+\delta_{1} S I Z E_{i}+\delta_{2} M T B_{i}+\delta_{3} L E V_{i} \\
& +\delta_{4} D_{i} S I Z E_{i}+\delta_{5} D_{i} M T B_{i}+\delta_{6} D_{i} L E V_{i}+\varepsilon_{i}
\end{aligned}
$$

Regression model in equation (4) is therefore estimated each year to obtain empirical estimators of $\mu_{i}$ and $\theta_{i}(\mathrm{i}=1,2,3,4)$. The estimators of CSCORE and GSCORE are as follows:

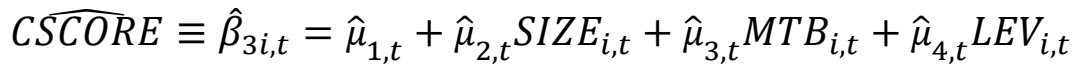

$$
\begin{aligned}
& G S \widehat{C O R} E_{l t} \equiv \hat{\beta}_{2 i, t}=\widehat{\theta}_{1, t}+\widehat{\theta}_{2, t} S I Z E_{i, t}+\widehat{\theta}_{3, t} M T B_{i, t}+\widehat{\theta}_{4, t} L E V_{i, t}
\end{aligned}
$$

$\widehat{C S C O R E}$ and GSCORE in equation (5) and (6) will vary across firms through crosssectional variation in the firm-year characteristics (SIZE, MTB and LEV), and over time through inter-temporal variation of $\mu_{i}$ and $\theta_{i}$ (Khan \& Watts, 2009). As the conditional conservatism measure (CSCORE) may be subject to measurement error, we transform its raw values into decile rank by ranking firms based on CSCORE into deciles in each year. Therefore, firms in the first decile have the smallest value of conditional conservatism. We denote this variable by CSCORE_RANK.

We also calculate alternative measures of conditional conservatism. Following Basu (1997), the first measure reflects the timeliness of bad news recognition (BNEWS) and is obtained at the firm-year level as:

$$
\widehat{B N E W} S=\widehat{C S C O R} E+G \widehat{S C O R} E
$$

The second measure is proposed by Gassen et al. (2013) called the "BASU_metric," and is a modification of the measure proposed by Pope and Walker (1999). The "BASU_metric" controls for the possibility that earnings response to both bad news and good news. The "BASU_metric" is calculated at the firm-year level as follows:

$$
B A S \widehat{U_{-} m} e t r l c=\operatorname{arctang}(\widehat{C S C O R} E+G \widehat{G C O R} E)-\operatorname{arctang}(\text { GCORE})
$$

\subsection{Cost of equity capital measure}


We adopt Estrada's (2000) methodology to measure the firm's cost of equity capital. Traditionally, the firm's cost of equity capital is obtained through the Capital Asset Pricing Model (CAPM) introduced by Markowitz (1952) and later used by Treynor (1961) and Sharpe (1964), to describe the relationship between risk and expected rate of return. Under CAPM model, we compute the cost of equity capital by estimating the relationship between systematic risk (Market beta) and stock returns. However, Estrada (2000) argues that in emerging markets betas and stock returns are largely uncorrelated. In addition, Harvey (1995) finds that such markets have low betas, which in turn produce a lower required rate of return when CAPM is used. To overcome the problem of low values of betas, Estrada (2000, 2001, 2004, and 2007) proposes a new method based on the downside risk approach. The model is as follows:

$$
C O E C_{i}=R f_{U S}+R m_{i} * R P_{W}
$$

Where COEC is the cost of equity capital of the firm i, $R f_{U S}$ is free-risk rate of the global market (US market), $R m_{i}$ is the risk measure of firm $\mathrm{i}$, and $R P_{W}$ is the premium risk of the global market. The risk measure proposed by Estrada (2000) is:

$$
\operatorname{Rm}_{i}=\frac{\Sigma_{\mu_{i}}}{\Sigma_{W}}
$$

Where:

$$
\Sigma_{\mu_{i}}=\sqrt{\frac{1}{T} \sum\left(R_{i}-\bar{R}\right)^{2} \text { forall }_{i}<\bar{R}}
$$

And

$$
\Sigma_{W}=\sqrt{\frac{1}{T} \sum\left(R_{M}-\bar{R}_{M}\right)^{2}} \text { forall }_{M}<\bar{R}_{M}
$$

$\Sigma_{\mu_{\mathrm{i}}}$ and $\Sigma_{W}$ designate respectively the value of the downside risk of firm $\mathrm{i}$ and the global market, where $\mathrm{R}$ is the monthly return of the firm, $\bar{R}$ is the annual average return, $R_{M}$ is the market return, and $\bar{R}_{M}$ is the annual average market return. Finally, following the Estrada approach, the measure of the cost of equity capital is as follows:

$$
\operatorname{COEC}_{i}=R f_{U S}+\frac{\Sigma_{\mu_{i}}}{\Sigma_{W}} *\left(R_{M}-R f_{U S}\right)
$$

3.3. Control variables 
We include two sets of control variables. The first set includes firm-specific control variables. Following Chan et al. (2009), Garcia et al. (2009), Khalifa and Ben Othman (2015), and Li (2015), we include firm size (SIZE), Market-to-Book ratio (MTB), leverage ratio (LEV), return on assets (ROA), and return volatility (RTVOL) to capture firm-specific uncertainty and earning volatility (EARVOL). We measure return volatility using the standard deviation of monthly stock return and it is employed instead of beta to measure stock market risk. Earning volatility is computed the coefficient of variation of earnings using a five-year rolling window and it is used to control for the volatility of business (Hail \& Leuz, 2006; Francis et al., 2005). All other variables defined in Table 1

The second set of control variables encloses country-specific factors to control for macroeconomic, institutional, and accounting standards differences. Following Hail and Leuz (2005) and Persakis and Iatridis (2016), and to control for differences across countries in the quality of legal system and investor protection, we include time-varying factors. We include two variables using data from the Global Competitiveness Report 2015-2016 by the World Economic Forum: 1) INVESPROT, scaled from 0 to 10 with higher scores representing greater investor protection; and 2) AUDIT, scaled from 1 to 7 with higher scores for stronger financial auditing and reporting standards. We also include the annual rate of inflation (INFLATION) and annual growth rate of Gross Domestic Product (GDP) (GDPG) from World Development Indicators. While most firm-specific variables are ratios, variables in levels (such as size) are expressed in US dollars. We winsorize all variables used in the regression model at $5 \%$ and $95 \%$ tails $^{1}$ (see Table 1 ).

\section{(Insert Table 1 about here)}

\subsection{Regression model}

We aim to examine the relationship between conditional conservatism and the cost of equity capital. Based on theoretical concepts of TMGT and TLGT effects, we hypothesized that the relationship is either U-shaped or inverted U-shaped. Both theoretical frameworks combine a negative and a positive association that can be represented by a quadratic functional form of the regression specification (Pierce \& Aguinis, 2013). The quadratic functional form

\footnotetext{
${ }^{1}$ Belsley et al. (1980) argue that observations having Cook's D-statistic greater than $4 /(n-k-1)$, where $n$ is the sample size and $\mathrm{k}$ is the number of covariates, can affect the estimation results. In estimating Eq. (7) on our full sample, we find that about $5-10 \%$ of the observations as such influential observations. Therefore, we winsorize our variables at the top and the bottom $5 \%$.
} 
incorporates CSCORE in the regression model as a linear term as well as a quadratic term. To allow the regression model to have a regular or an inverted U-shape, the standard approach has been to include a quadratic term in a linear form of the model (Lind \& Mehlum, 2010). The linear term (CSCORE) works as the predictor of the effect of conditional conservatism on the cost of equity capital and the quadratic term $\left(\mathrm{CSCORE}^{2}\right)$ works as a moderator (Pierce \& Aguinis, 2013). Greene (2008) argues that if the suspected nonlinearity relates to a single explanatory variable, then fitting a quadratic functional form rather than a linear function may capture some of the nonlinearity. The resulting quadratic functional form is a linear model, which has linear coefficients but nonlinear variables (Greene, 2008). Accordingly, to test the type of the relationship between conditional conservatism and the cost of equity capital, we construct the following regression model:

$$
\begin{aligned}
\operatorname{COEC}_{i t}=\beta_{0} & +\beta_{1} \operatorname{CSCORE}_{i, t}+\beta_{2} \operatorname{CSCORE}_{i, t}^{2}+\beta_{3} \operatorname{SIZE}_{i, t}+\beta_{4} \operatorname{LEV}_{i, t}+\beta_{5} \operatorname{ROA}_{i, t} \\
& +\beta_{6} \operatorname{RTVOL}_{i, t}+\beta_{7} \text { EARVOL }_{i, t}+\sum_{k=8}^{K} \beta_{k} \boldsymbol{X}_{\text {kit }}+\sum \beta_{j} \text { country }_{j} \\
& +\sum \beta_{k} \text { Industry }_{k}+\varepsilon_{i, t}
\end{aligned}
$$

Where COEC $_{i t}$ is the cost of equity capital measure of firm $i$ in year $t$. CSCORE $i t$ is the linear term measuring the level of conditional conservatism of firm $\mathrm{i}$ in year $\mathrm{t}$ and $\mathrm{CSCORE}^{2}{ }_{\text {it }}$ is squared of CSCORE. $\boldsymbol{X}_{\boldsymbol{k i t}}$ is a vector of country-specific control variables as discussed above. The definitions of all variables are given in Table 1. In equation (7), our main coefficients are $\beta_{1}$ and $\beta_{2}$. When $\beta_{1}>0$ and $\beta_{2}<0$, it indicates that the relationship is an inverted-U shaped and When $\beta_{1}<0$ and $\beta_{2}>0$, it indicates that the relationship is $U$ shaped.

We estimate Equation (7) using pooled OLS. To handle the firm effects in our panel dataset, we use a one-way clustered OLS panel regression, as recommended by Petersen (2009). That is, we estimate our regression model with robust standard errors clustered at the firm level to account for potential serial correlation and heteroscedasticity in the dataset.

\subsection{Sample selection}

We collect our data from public firms followed by Standard and Poor's (S\&P) and included in their S\&P/IFC (International Financial Corporation) emerging market indices. While the Credit Lyonnais Securities Asia (CLSA) and the FTSE institutional shareholder services (ISS) focus on, respectively, developed markets and Asia emerging markets, S\&P covers many more emerging markets (Ben Othman \& Zeghal, 2010). In our sample, all firms 
must be domiciled in an emerging market (S\&P/IFCG (International Financial Corporation Global)) or a lesser-developed global frontier market (S\&P/IFCG frontier) and among the most actively traded securities in the market. Following Morgan Stanley Capital International (MSCI) and S\&P classification, our preliminary sample covers 62 countries (38 emerging countries and 24 frontier emerging countries). However, with missing data for some variables, our final sample covers only 37 countries. Table 2 reports the list of countries.

\section{(Insert Table 2 about here)}

To construct our final sample, we proceed as follows: First, financial and accounting data are obtained from Thomson One database during for the period of 2003 to 2012. Second, each country should have at least 20 observations during the sample period in order to obtain a reliable estimate of CSCORE (Jayaraman, 2012). Third, all observations with missing values are deleted. Fourth, we exclude financial industries (SIC 6000-6999) from our sample due to their different nature business and specific regulations (Li, 2015). Finally, we delete firms with a negative book value of equity and firms with a negative cost of equity capital. The final sample consists of 43,995 firm-year observations covering 37 emerging countries from 2003 to $2012^{2}$.Table 3 describes the sample distribution of firms by year for each country. $16.80 \%$ of observations are from China (CHN), followed by Taiwan (TWN), South Korea (KOR), and India (IND) with $15.44 \%, 14.18 \%$, and $11.46 \%$ of total observations, respectively. These four countries alone account for $57.88 \%$ of firm-year observations. To ensure that our estimations are not derived by any of these countries, we delete each country individually and together from the sample and estimate our primary regression model (the results are reported in section 5).

\section{(Insert Table 3 about here)}

\section{Empirical results}

\subsection{Descriptive statistics and correlation matrix}

Table 4 reports descriptive statistics of the data. Panel A of Table 4 summarizes descriptive statistics of conditional conservatism and the cost of equity capital measures by country and the country-level regression variables. Panel A of Table 4 reports that the mean value of the cost of equity capital varies between $40.06 \%$ for Turkey and $16.03 \%$ for Jordan.

\footnotetext{
${ }^{2}$ Our sample period is not continuous in time. The data for the year 2008 is removed for two reasons (1) missing data for some variables of interest for this particular year and also (2) deleting a large number of firms in 2008 with negative cost of equity capital.
} 
Overall, these results are similar to those reported by Estrada (2000). It should be noted that the values of the cost of equity capital we report are higher than those reported by previous studies using a sample of developed countries (i.e. Hail and Leuz, 2006; Li, 2015). This result is consistent with the fact that emerging markets have different macroeconomic, political, and financial environments that are particularly characterized by higher volatility, thinness of trading, high transaction costs, illiquidity in the market, mispricing of assets, asymmetric information, and less protected investors (Aggarwal et al. 1999; Estrada, 2000; Bekaert \& Harvey, 2002; Alam et al., 2007; Ciner \& Karagozoglu, 2008), and which in turn may lead to a higher cost of equity capital (Botosan \& Plumlee, 2002; Hail \& Leuz, 2006).

\section{(Insert Table 4 about here)}

We find mixed results among countries with regard to the conditional conservatism measure (CSCORE). Specifically, we find that countries with higher investor protection (INVESPROT), such as Malaysia, Israel, Colombia, and South Africa, are more conservative. This result is in line with the findings of Bushman and Piotroski (2006).

Panel B of Table 4 summarizes firm-level descriptive statistics of our main variables. We report the mean, the standard deviation, the median, the first quartile, the Third quartile, the minimum, and the maximum values. The mean (median) value of the CSCORE variable is $0.014(0.015)$. The cost of equity capital has a mean of $32.3 \%$ with a standard deviation of $25.1 \%$.

Panel C of Table 4 reports Pearson's pair-wise correlation matrix between the firm-level and country-level variables included in the regression analysis. As predicted, the cost of equity capital (COEC) is negatively correlated with the conditional conservatism measure (CSCORE). Furthermore, we find that the cost of equity capital is positively correlated with the firm's size (SIZE), the market-to-book ratio (MTB), earnings volatility (EARVOL), monthly return volatility (RTVOL), return on assets (ROA) ratio, annual GDP growth (GDPG), annual inflation rate (INFLATION), investor protection index (INVESPROT), and the strength of auditing and reporting index (AUDIT). In addition, we find that the conservatism measure is negatively associated with the firm's size, return volatility, and positively correlated with the strength of investor protection index and the strength of auditing and reporting index. These results are consistent with the finding of Bushman and Piotroski (2006) and Jayaraman (2012). 
The correlation matrix reveals no correlations above 0.5 , indicating that multicollinearity is not likely a concern.

\subsection{Stylized facts}

Before estimating our regression model, we first analyze some stylized facts on the relationship between conditional conservatism and the cost of equity capital. We begin by plotting scatter diagrams for the association between the cost of equity capital and conditional conservatism (Fig 1.), and between the cost of equity capital and two desegregate measures of conditional conservatism, namely timeliness of bad news recognition (Fig. 2.) and timeliness of good news recognition (Fig. 3). As seen in Fig. 1, Fig. 2, and Fig. 3, the relationship between the cost of equity capital and conditional conservatism, no matter if measured by CSCORE, BNEWS, or BASU_metric, is clearly not monotonic. The scatter diagrams show that at low levels of conservatism, an increase in conditional conservatism is associated with a decrease in the cost of equity capital. However, there seems to be an optimal point after which the negative effect of conditional conservatism on the cost of equity capital becomes positive (for higher levels of conservatism). Accordingly, based on these stylized facts, one can say that there is likely a U-shaped association between conditional conservatism and the cost of equity capital.

\section{(Insert Figures 1, 2 and 3 about here)}

To confirm the result of the likely U-shaped relationship between conditional conservatism and the cost of equity capital, we conduct an appropriate $U$ test as proposed by Lind and Mehlum (2010). The U test gives necessary and sufficient conditions to validate the existence of a $\mathrm{U}$ shaped or an inverted U-shaped relationship. To illustrate how the test works, consider the following general regression model:

$$
y_{i}=\alpha+\beta x_{i}+\gamma f\left(x_{i}\right)+\delta z_{i}+\varepsilon_{i} \quad i=1,2, \ldots, n
$$

Where $y$ is the dependent variable (COEC), and where $x$ is the main explanatory variable of interest (CSCORE), $\mathrm{z}$ is a vector of control variables, and $\varepsilon$ is an error term. $f($.$) is a known$ function which gives equation (8) a curvature of the form of $U$-shaped if the parameters $\beta$ and $\gamma . f($.$) are assumed to have at most one extreme point on the interval \left[\mathrm{X}_{l}, \mathrm{X}_{h}\right]$, where $\mathrm{X}_{l}$ and $\mathrm{X}_{h}$ are the minimum and the maximum values of the variable $x$, respectively. To assure at most one optimal point, the first derivative of $f(),. f^{\prime}$, should be monotone on $\left[\mathrm{X}_{l}, \mathrm{X}_{h}\right]$. If a U shaped curve is assumed, this implies the following conditions: 


$$
\beta+\gamma f^{\prime}\left(x_{l}\right)<0<\beta+\gamma f^{\prime}\left(x_{h}\right)
$$

If the inequalities given in equation (9) are violated, the relationship is not a U-shaped but rather an inverted $\mathrm{U}$-shaped or monotone. To test whether these conditions are statistically significant, we test the following combined null hypothesis:

$$
H_{0}: \beta+\gamma f^{\prime}\left(x_{l}\right) \geq 0 \text { and/or } \beta+\gamma f^{\prime}\left(x_{h}\right) \leq 0
$$

The alternative hypothesis is:

$$
H_{1}: \beta+\gamma f^{\prime}\left(x_{l}\right)<0 \text { and } \beta+\gamma f^{\prime}\left(x_{h}\right)>0
$$

If equation (8) is specified as a quadratic form (i.e $f(x)=x^{2}$ ), the presence of a U shaped implies that $\beta+2 \gamma x_{l}<0$ and $\beta+2 \gamma x_{h}>0$. In this case, the optimal point is estimated as $-\frac{\widehat{\beta}}{2 \widehat{\gamma}}$. The results of the U test as well as the corresponding Fieller's (1954) confidence interval are reported in Table 5. The results reported in Table 5 show that the slope at $x_{l}(\hat{\beta}+$ $\left.2 \hat{\gamma} x_{l}\right)$ is negative and the slope at $x_{h}\left(\hat{\beta}+2 \hat{\gamma} x_{h}\right)$ is positive. In addition, the appropriate $\mathrm{U}$ test is significant at the $1 \%$ level for all measures of conditional conservatism. The test rejects the null hypothesis of an inverted U-shaped or monotonic relationship. Therefore, with the appropriate $\mathrm{U}$ test along with the scatter diagrams, we can confirm the existence of a U-shaped, nonlinear relationship between conditional conservatism and the cost of equity capital.

\section{(Insert Table 5 about here)}

\subsection{Regression results}

Table 6 reports the basic regression results of Equation (7), which tests the effect of conditional conservatism on the cost of equity capital. Panel A presents the regression results using raw values of CSCORE and Panel B presents results using deciles rank of conservatism measure (CSCORE_RANK). We report both the results from the linear form of Equation (7) (i.e. excluding the squared term of CSCORE) and from the quadratic form. For each form, regression results without and with control variables (SIZE, MTB, LEV, EARVOL, ROA, RTVOL, GDPG, INFLATION, INVESPROT, and AUDIT) are reported in columns (1), (2), and (3), respectively. 
With regard to the linear relationship, the level term of conditional conservatism (CSCORE and CSCORE_RANK) is estimated to be negatively associated with the cost of equity capital (COEC) at $1 \%$ significance level for all specifications. This evidence implies that more conditional conservatism is associated with a lower cost of equity capital. The result is consistent with theoretical models which argue that accounting conservatism enhances overall financial information quality and reduces the cost of equity capital. In addition, this finding is in line with previous empirical studies (Garcia et al., 2011, Artiach \& Clarckson, 2014; Li, 2015; Khalifa \& Ben Othman, 2015, Khalifa et al., 2018).

We now present regression results from the quadratic form. As can be highlighted from columns (1), (2), and (3) under the quadratic relationship, the coefficient of the CSCORE (CSCORE_RANK) variable is negative and statistically significant at $1 \%$ level, while its quadratic term $\left(\mathrm{CSCORE}^{2}\right.$ (CSCORE_RANK $\left.{ }^{2}\right)$ ) is estimated to be positively associated with the cost of equity capital at the $1 \%$ significance level. This finding strongly suggests that the relationship between conditional conservatism and the cost of equity capital is nonlinear, specifically U-shaped. That is, there exists an optimal point (a minimum) after which the negative effect of conditional conservatism on the cost of equity capital becomes positive. The above findings are generally consistent with the TLGT effect, which suggests that the relationship between accounting conservatism and the cost of equity capital follows a $U$-shaped curve as posited by hypothesis $\mathrm{H} 2$.

\section{(Insert Table 6 about here)}

With regard to control variables, the regression results are similar to the finding of Garcia et al. (2011), Artiach and Clarckson (2014), Li (2015), Khalifa and Ben Othman (2015), Persakis and Iatridis (2016), and Khalifa et al. (2018). Specifically, Table 6 reports that the coefficients of earnings volatility (EARVOL), monthly return volatility (RTVOL), and strength of investor protection (INVESPROT) are positive and significant with the cost of equity capital. In addition, we find that the cost of equity capital is negatively associated with firm's size (SIZE), financial leverage (LEV), return on assets (ROA), Market-to-Book ratio (MTB), annual change in GDP (GDPG), inflation rate (INFLATION), and strength of auditing and reporting standards (AUDIT).

\section{Robustness tests}


In this section, we examine the sensitivity of our results by conducting a set of robustness checks, including alternative measures of conditional conservatism, different samples, and alternative estimation strategies.

\subsection{Alternative measures of conditional conservatism}

We carry out additional tests on the effect of accounting conservatism on the cost of equity capital using alternative proxies of conditional conservatism at the firm level. Specifically, we use the timeliness of bad news recognition (BNEWS) and the BASU_metric proposed by Gassen et al. (2013). Table 7 reports the results.

\section{(Insert Table 7 about here)}

Consistent with the results from Table 6 , Table 7 shows that the coefficients on the level and quadratic term of conditional conservatism as measured by the BNEWS and BASU_metric are all statistically significant with the predicted sign. These findings suggest that the U-shaped relationship between conditional conservatism and the cost of equity capital holds even after using different proxies of conditional conservatism. Again, these results show that the decreasing effect of accounting conservatism on the cost of equity capital is likely to reverse after the level of conditional conservatism reach a certain threshold.

\subsection{Excluding countries with a higher sample size}

Recall from subsection 3.5 that China (CHN), Taiwan (TWN), South Korea (KOR), and India (IND) alone account for $57.88 \%$ of firm-year observations. To ensure that results for the pooled sample are not being driven by these countries, we re-estimate our primary regression by first deleting each one of these countries and secondly by deleting all four countries. Table 8 reports the results and shows that the coefficients on the level and the quadratic terms of conditional conservatism are negative and positive, respectively, and statistically significant at $1 \%$ level in every instance. These findings suggest that our results remain unchanged when excluding some countries with a higher sample size.

\section{(Insert Table 8 about here)}

\subsection{Alternative estimation strategies}

\subsubsection{Panel data regression: Fixed and random effects models}


Pooled OLS methodology is widely used in empirical literature to estimate the crosssectional regression model. However, this technique may omit important independent variables, which could affect the quality of estimations. Our sample appears as panel data; therefore, it is important to take advantage of panel regression techniques. Baltagi (2005) argues that when the sample is panel data, panel regression will produce more efficient estimations than pooled OLS. In this section, we estimate our baseline regression using a fixed effects (FE) model. In the presence of unobservable firm-fixed specific factors, the FE model is commonly used in the empirical studies (Wooldridge, 2002). However, the FE model may suffer from some drawbacks. For example, Baltagi (2005, p.4) stipulates the FE model may produce inconsistent estimators where there is a large number of firms ' $\mathrm{N}$ ' and a fixed small time ' $\mathrm{T}$ ', which is the case of our study $(\mathrm{N}=9800$ firms, and $\mathrm{T}=9)$. So we introduce into our econometric models variables that do not vary much over time, such as the strength of investor protection index or the strength of auditing and reporting standards index. Consequently, FE estimates would produce an inefficient estimator (Wooldridge, 2002, p. 286). For that, we also use the generalized least square (GLS) random effect (RE) technique following the Baltagi and $\mathrm{Wu}$ (1999) procedure as an alternative approach to the FE model. Estimations are made using the three proxies of conditional conservatism (i.e. CSCORE, BNEWS, and BASU_metric). All regressions are estimated with robust standard errors clustered at the firm level in order to take into account possible heteroscedasticity and serial correlations in the data. Table 9 reports the results of estimations. We find that the coefficients on the conditional conservatism variable and its quadratic term are all statistically significant with the same sign as the baseline regression.

\section{(Insert Table 9 about here)}

\subsubsection{Quantile regression}

Classical linear regression describes a response variable as a linear function of one or a set of covariates and the parameters of the linear model are estimated using the well-known cross-sectional or pooled OLS approach. OLS regression provides point estimations that describe the mean effect of covariates on the response variable. That is, it identifies the conditional mean association or a central tendency between conditional conservatism and the cost of equity capital. OLS regression produces estimators that are optimal if error terms are independent, identical distributed, and follow a normal distribution. However, these assumptions may not hold, especially when the dependent variable has a skewed distribution 
caused by potentially extreme observations which may affect the quality of the estimations. To avoid this problem, we use the quantile regression approach initially proposed by Koenker and Basset (1978). Quantile regression is superior to OLS regression, especially when the relationship between the cost of equity capital and conditional conservatism is not uniform across the quantiles of the cost of equity capital variable (Koenker \& Basset, 1978). Therefore, the conditional mean (OLS) may not well describe the relationship when the cost of equity capital is in its extreme upper or lower tails. Besides, the quantile regression method can produce estimations at any point in the conditional distribution of the cost of equity capital. The quantile regression provides a more complete picture of the association between the cost of equity capital and conditional conservatism.

Table 10 reports the results of the quantile regression. Estimations are conducted at 9 quantiles, namely the 10th, 20th, 30th, 40th, 50th, 60th, 70th, 80th, and $90^{\text {th }}$ quantile ${ }^{3}$. We also conduct an F-test to check the significance of the differences with regard to the coefficients of CSCORE and $\mathrm{CSCORE}^{2}$ variables across different cost of equity capital quantiles. Panel A of Table 10 reports the results of estimation from the quantile regression and Panel B of Table 10 reports F-test statistics. While the estimated coefficients of the CSCORE variable are negative and statistically significant for all quantiles, they are positive and significantly different from zero for the quadratic term CSCORE ${ }^{2}$. The F-statistics reported in Panel B show that the coefficient differences across upper and lower quantiles are statistically significant, suggesting that the effect of conditional conservatism on the cost of equity capital varies across quantile. Summarizing, we find through quantile regression that the coefficients of CSCORE and its quadratic term, $\mathrm{CSCORE}^{2}$, are with the predicted sign and are stable and consistent across all quantiles.

\section{(Insert Table 10 about here)}

\subsubsection{Piecewise linear regression}

In order to confirm the nonlinear relationship between the cost of equity capital and conditional conservatism, we also use the piecewise linear regression as suggested by Morck et al. (1988). Contrary to the quadratic regression, this methodology requires the division of conditional conservatism measure (CSCORE) into three following items:

\footnotetext{
${ }^{3} \mathrm{We}$ also conduct more detailed quantile regressions for every 5-percentile. The results hold the same and are available upon request.
} 
CSCORE_(MEDIAN) $=$ CSCORE if CSCORE $\leq$ median, and the median value otherwise. CSCORE_(MEDIAN-Q3) $=0$ when CSCORE $\leq$ median; and if median $<$ CSCORE $<$ Q3 $\left(75^{\text {th }}\right.$ percentile $),$ CSCORE_(MEDIAN-Q3) = CSCORE - median; otherwise, CSCORE_(MEDIAN$\mathrm{Q} 3)=\mathrm{Q} 3$. CSCORE_(Q3) $=0$ if CSCORE $<\mathrm{Q} 3$; and if CSCORE $\geq \mathrm{Q} 3$, CSCORE_(Q3) = CSCORE-Q3. This piecewise approach allows the coefficient to change at median and Q3.

Table 11 shows that the findings of our piecewise regressions are consistent with previous results. We find a negative and significant relationship between the cost of equity capital and conditional conservatism when CSCORE is less than the median value. Also, the coefficient of interest is positive and statistically significant when CSCORE is more than the median value. These results are suggestive of a concavely shaped relationship between the cost of equity capital and conditional conservatism. In addition, we find that CSCORE is negatively related with the cost of equity capital when CSCORE is greater than $75^{\text {th }}$ percentile value. Altogether, the findings from the piecewise linear regression suggest that the relation between the cost of equity capital and conditional conservatism is nonlinear.

\section{(Insert Table 11 about here)}

\subsection{Other robustness analysis}

As mentioned previously, the data for 2008 is missing and may affect the result of our estimations. To ensure that this gap in the dataset does not have any economic impact on the analysis, we conduct two additional robustness checks. The first consists of re-estimating our model by splitting the sample into two sub-periods 2003-2007 and 2009-2012. Table 12 reports the results using the three measures of accounting conservatism (CSCORE, BNEWS, and BASU_metric). As seen in Table 12, the coefficients of conservatism variables are negative and statically significant for each sub-period. However, the coefficients of the quadratic term $\left(\right.$ Conservatism $\left.^{2}\right)$ are positive and significant at conventional level of $1 \%$ for each sub-period. This finding suggests that our estimations are stable and robust to change of the period of analysis.

\section{(Insert Table 12 about here)}

Following the approach of Baltagi and Wu (1999), the second robustness check is a panel regression with unequally spaced data. We use feasible generalized least squares for unbalanced data as weighted least squares that allows for a range of unequally spaced panel 
data patterns. Table 13 displays estimation results of the unequally spaced panel data regression using the three measure of conditional conservatism. The table shows that the coefficients of the linear form of the conservatism variable are negative and significant, but the coefficient of the quadratic term of conservatism is positive for all specifications. Overall, these findings suggest that our estimations are robust even if there is a gap in our dataset.

\section{(Insert Table 13 about here)}

\section{Conclusion}

This paper expands on the economic consequences of accounting conservatism literature. We investigate whether there is evidence for a nonlinear association between conditional conservatism and the cost of equity capital in the form of a U-shaped or inverted U-shaped curve. We use a sample of non-financial firms pertaining to 37 emerging countries during the period 2003-2012. We use the downside risk approach by Estrada (2000) to measure the extent of the cost of equity capital and the Khan and Watts (2009) methodology to estimate the level of conditional conservatism at firm-year level. Based on pooled OLS regression, we find strong evidence that conditional conservatism has a U-shaped effect of the cost of equity capital. That is, conditional conservatism is beneficial for firms by reducing its cost of equity capital only up to an optimal point, after which an increase in the level of conditional conservatism induces an increase in the cost of equity capital. Our findings are robust to alternative proxies of conditional conservatism, different sample size, and alternative estimation strategies including panel regression, quantile regression, and piecewise regression.

Despite the implications and the contributions provided by the findings of this paper, this study may suffer from some drawbacks, which may be treated as avenues of future research. The first one is the use of one measure of conditional conservatism and the cost of equity capital knowing that empirical literature offers other measures that are widely used. Second, our sample period covers the financial crisis, and previous studies reported evidence of the influence of the crisis on the cost of equity capital as well as on the level of accounting conservatism. Therefore, our estimations may be affected by the financial crisis period. Third, our sample regroups countries from different legal regimes and with different culture. Hail and Leuz (2006) and Bushman and Piotroski (2006) show that the cost of equity capital and accounting conservatism are derived by institutional factors and culture values. Therefore, our findings may be affected by these differences between countries. Future studies on the 
association between accounting conservatism and the cost of equity capital should consider incorporating these factors into the analysis. In addition, prior research finds that a firm's life cycle stage affects both its reporting conservatism (Hansen et al., 2017) its cost of equity capital (Hasan et al., 2015). Therefore, it would be interesting to test how the effect of conservatism on the cost of equity capital varies across a firm's life cycle stage.

\section{References}

Aboody, D., Hughes, J., \& Liu, J. (2005). Earningsquality, insider trading, and cost of capital. Journal of Accounting Research, 43, 651-673.

Aggarwal, R., Inclan, C., \& Leal, R. (1999). Volatility in emerging stock markets. The Journal of Financial and Quantitative Analysis, 34(1), 33-55.

Akins, B., Ng, J., \& Verdi, R. (2012). Investor competition over information and the pricing of information asymmetry. The Accounting Review, 87(1), 35-58.

Alam, M.M., Alam, K.A., \& Uddin, M.G.S. (2007). Market depth and risk return analysis of Dhaka stock exchange: An empirical test of market efficiency. ASA University Review, $1(1), 93-101$.

Armstrong, C., Core, J., Taylor, D., \& Verrecchia, V. (2011). When does information asymmetry affect the cost of capital? Journal of Accounting Research, 49(1), 1-40.

Artiach, T., \& Clarkson, P. (2014). Conservatism, disclosure and the cost of equity capital. Australian Journal of Management, 38, 293-314.

Bagnoli, M., \& Watts, S. (2005). Conservative accounting choices. Management Science, 51, 786-801.

Ball, R. (2001). Infrastructure requirements for an economically efficient system of public financial reporting and disclosure. Brookings Wharton Papers on Financial Services, 127-169. Project MUSE, DOI:10.1353/pfs.2001.0002.

Baltagi, B.H. (2005). Econometric Analysis of Panel Data (3rd Edition). John Wiley \& Sons Inc., New York.

Baltagi, B.H., \& Wu, P.X. (1999). Unequally spaced panel data regressions with AR (1) disturbances. Econometric Theory, 15, 814-823. 
Basu, S. (1997). The conservatism principle and the asymmetric timeliness of earnings, Journal of Accounting and Economics, 24, 3-37.

Bekaert, G., \& Harvey, C. R. (2002). Research in emerging markets finance: Looking to the futures. Emerging Markets Review, 3, 429-448.

Belsley, D., Kuh, E., \& Welsch, R. E. (1980). Regression diagnostics: Identifying influential data and sources of collinearity. New York: Wiley.

Ben Othman, H., \& Zeghal, D. (2010). Investigating transparency and disclosure determinants at firmlevel in MENA emerging markets. International Journal of Accounting, Auditing and Performance Evaluation, 6, 368-96.

Biddle, G., C., Ma, M., L., Z., \& Wu, F. (2016). Conditional conservatism and the cost of equity capital: Information precision and information asymmetry effects. Applied Finance and Accounting, 2, 69-88.

Biddle, G.M., \& Wu, F. (2012). Conditional conservatism and the cost of equity capital: informational, fundamental, and behavioral effects. Working paper, University of Hong Kong. Available from http://hkir.ust.hk/hkir/Record/9999-728193.

Botosan, C. A., \& Plumlee, M. A. (2002). A re-examination of disclosure level and the expected cost of equity capital. Journal of Accounting Research, 40, 21-40.

Botosan, C. A. (1997). Disclosure level and the cost of equity capital. The Accounting Review, 72, 323-349.

Botosan, C. A. (2006). Disclosure and the cost of capital: what do we know? Accounting and Business Research, 36, 31-40.

Bushman, R. M., \& Piotroski J. D. (2006). Financial reporting incentives for conservative accounting: The influence of legal and political institutions. Journal of Accounting and Economies, 42, 107-148.

Callen, J. L., Segal, D., \& Hope, O. K. (2010). The pricing of conservative accounting and the measurement of conservatism at the firm-year level. Review of Accounting Studies, 15 (1), 145-178.

Chan, A. L.-C., Lin, S. W. J., \& Strong, N. (2009). Accounting conservatism and the cost of equity capital: UK evidence. Managerial Finance, 35, 325 -345.

Chang, H., Fernando, G., \& Liao, L. (2009). Sarbanes-Oxley act, perceived earnings quality and cost of capital. Review of Accounting and Finance, 8(3), 216-231. 
Chen, Q., Hemmer, T., \& Zhang, Y. (2007). On the relation between conservatism in accounting standards and incentives for earnings management. Journal of Accounting Research, 45, 541-565.

Ciner, C., \& Karagozoglu, A. K. (2008). Information asymmetry, speculation and foreign trading activity: Emerging market evidence. International Review of Financial Analysis, 17(4), 664-680.

Demski, J., \& Feltham, G. (1994). Market response to financial reports. Journal of Accounting and Economics, 17(1-2), 3-40.

Diamond, D., \& Verrecchia, R. (1981). Information aggregation in a noisy rational expectations economy. Journal of Financial Economics, 9, 221-303.

Easley, D., \& O’Hara, M. (2004). Information and the cost of capital, The Journal of Finance, 59, 1553-1583.

Estrada, J. (2000). The cost of equity in emerging markets: a downside risk approach. Emerging Markets Quarterly, 3, 19-30.

Estrada, J. (2001). The cost of equity in emerging markets: A downside risk approach (II), Emerging Markets Quarterly, 5, 63-72.

Estrada, J. (2004). The cost of equity of internet stocks: a downside risk approach. The European Journal of Finance, 10, 239-254.

Estrada, J. (2007). Mean-semi variance behavior: downside risk and capital asset pricing. International Review of Economics and Finance, 16, 169-85.

Fama, E. F., \& French, K. R. (1992). The Cross-Section of Expected Stock Returns. The Journal of Finance, 47, 427-465.

Fan, Q., \& Zhang, X. J. (2012). Accounting conservatism, aggregation, and information quality. Contemporary Accounting Research, 29, 38-56.

Fieller, E. C. (1954). Some problems in interval estimation. Journal of Royal Statistical Society. Ser. B, 16, 175-185.

Financial Accounting Standards Board (FASB). (2010). Statement of Financial Accounting Concepts No. 8, Conceptual framework for financial reporting. Norwalk, CT: FASB. 
Francis, J., LaFond, R., Olsson, P., \& Schipper, K. (2004). Cost of equity and earnings attributes. The Accounting Review, 79, 967-1010.

Francis, J., Lafond, R., Olsson, P., \& Schipper, K. (2005). The market pricing of accruals quality. Journal of Accounting and Economics, 39, 295-327.

García Lara, J., García Osma, B., \& Penalva, F. (2011). Conditional conservatism and cost of capital. Review of Accounting Studies, 16, 247-271.

Gassen, J., Rolf, U.F., \& Thorsten, S. (2013). International differences in conditional conservatism - the role of unconditional conservatism and income smoothing. European Accounting Review, 15(4), 527-564.

Gietzmann, M., \& Trombetta, M. (2003). Disclosure interactions: accounting policy choice and voluntary disclosure effects on the cost of raising outside capital. Accounting and Business Research, 33, 187-205.

Gigler, F., Kanodia, C., Sapra, H., \& Venugopalan, R. (2009). Accounting conservatism and the efficiency of debt contracts. Journal of Accounting Research, 47, 767-797.

Gow, I. D., Taylor, D. J., \& Verrecchia, R. E. (2011). Disclosure and the cost of capital: Evidence of information complementarities. Working Paper, University of Pennsylvania.

Greene W. H. (2008). Econometric Analysis. (6th ed.). New Jersey: Prentice Hall.

Guay, W., \& Verrecchia, R. (2006). Discussion of an economic framework for conservative accounting and Bushman and Piotroski (2006). Journal of Accounting and Economics, 42(1-2), 149-165.

Guay, W. R., \& Verrecchia R, E. (2018). Conservative disclosure. Journal of Financial Reporting, Fall, 3(1), 73-92.

Guenther, E., \& Hoppe H. (2014). Merging limited perspectives: a synopsis of measurement approaches and theories of the relationship between corporate environmental and financial performance. Journal of Industrial Ecology, 18(5), 689-707.

Hail, L., \& Leuz, C. (2006). International differences in the cost of equity capital: do legal institutions and securities regulation matter? Journal of Accounting Research, 44, 485-531. 
Harvey, R., C. (1995). Predictable risk and returns in emerging markets. Review of financial Studies, 8, 773-816.

Helbok, G., \& Walker, M. (2004). On the nature and rationality of analysts' forecasts under earnings conservatism. British Accounting Review, 36(1), 45-77.

Hu, J., Yuansha Li, A., \& Zhang, F. (2014). Does accounting conservatism improve the corporate information environment? Journal of International Accounting, Auditing and Taxation, 23(1), 32-43.

Jayaraman, S. (2012). The effect of enforcement on timely loss recognition: Evidence from insider trading laws. Journal of Accounting and Economics, 53, 77-97.

Johnstone, D. (2016). The effect of information on uncertainty and the cost of capital. Contemporary Accounting Research, 33(2), 752-774.

Khalifa, M., \& Ben Othman, H. (2015). The effect of conservatism on cost of capital: MENA evidence. Applied Economics, 47, 71-87.

Khalifa, M., Ben Othman, H., \& Hussainey, K. (2018). The effect of ex ante and ex post conservatism on the cost of equity capital: A quantile regression approach for MENA countries. Research in International Business and Finance, 44, 239-255.

Khan, M., \& Watts, R. (2009). Estimation and empirical properties of a firm-year measure of accounting conservatism. Journal of Accounting \& Economics, 48, 132-150.

Kim, J., B., \& Sohn, B. C. (2013). Real earnings management and cost of capital. Journal of Accounting and Public Policy, 32, 518-543.

Kim, O., \& Verrecchia, R. (1991). Market reaction to anticipated announcements. Journal of Financial Economics, 30(2), 273-309.

Koenker, R., \& Bassett, G. (1978). Regression Quantiles. Econometrica, 46 (1), 33-50.

La Porta, R., Lopez de Silanes, F., Shleifer, A., \& Vishny, R. (1998). Law and finance. Journal of Political Economy, 106, 1113-1155.

LaFond, R., \& Watts, R. L. (2008). The Information Role of Conservatism. Accounting Review, $83,447-478$. 
Lambert, R., Leuz, C., \& Verrecchia, R. (2007). Accounting information, Disclosure and the cost of capital.Journal of Accounting Research, 45(2), 385-420.

Lambert, R., Leuz, C., \& Verrecchia, R. (2011). Information asymmetry, information precision, and the cost of capital. Review of Finance, 16, 1-29.

Li, X. (2015). Accounting conservatism and cost of capital: International analysis. Journal of Business Finance and Accounting, 42, 555-582.

Lind, J. T., \& Mehlum, H. (2010). With or without U? - The appropriate test for a U-Shaped relationship. Oxford Bulletin of Economics and Statistics, 72(1), 109-118.

Louis, H., Lys, T., \& Sun, A. X. (2014). Conservatism and analyst earnings forecast bias. Working paper, Pennsylvania State University.

Markowitz, H. (1959). Portfolio Selection. New Haven and London: Yale University Press.

McInnis, J. (2010). Earnings smoothness, average returns, and implied cost of equity capital. The Accounting Review, 85(1), 315-341.

McNichols, M., \& Trueman, B. (1994). Public disclosures, private information collection, and short-term trading. Journal of Accounting and Economics, 17(1-2), 69-94.

Mensah, Y. M., Song, X., \& Ho, S. S. M. (2004). The effect of conservatism on analysts' annual earnings forecast accuracy and dispersion. Journal of Accounting, Auditing \& Finance, 19(2), 159-183.

Morck, R., Shleifer, A.. \& Vishny, R. (1988). Management ownership and market valuation: An empirical analysis. Journal of Financial Economics, 20, 293-315.

Nan, L., \& Wen, X. (2011). Conservatism's effects on capital structure efficiency and information quality. Working paper, Carnegie Mellon University.

Pae, J., \& Thornton, D. B. (2010). Association between accounting conservatism and analysts' forecast inefficiency. Asia-Pacific Journal of Financial Studies, 39(2), 171-197.

Persakis, A., \& Iatridis, G. E. (2017). The joint effect of investor protection, IFRS and earnings quality on cost of capital: An international study. Journal of International Financial Markets, Institutions and Money, 46, 1-29.

Petersen, M. A. (2009). Estimating standard errors in finance panel data sets: Comparing approaches. Review of Financial Studies, 22(1), 435-480. 
Pierce, J. R., \& Aguinis, H. (2011). The Too-Much-of-a-Good-Thing effect in management. Journal of Management, 39(2), 313-338.

Pope, P. E., \& Walker, M. (2003). Ex-ante and Ex-post accounting conservatism, asset recognition and asymmetric earnings timeliness. Working Paper, Lancaster University/ University of Manchester.

Ruch, G.W., \& Taylor G. (2015). Accounting conservatism: A review of the literature. Journal of Accounting Literature, 34, 17-38.

Sharpe, W. (1964). Capital asset prices: A theory of market equilibrium under conditions of risk. The Journal of Finance, 19(3), 425-442.

Suijs, J. (2008). On the value relevance of asymmetric financial reporting policies. Journal of Accounting Research, 46, 1297-1321.

Treynor, J. L. (1961). Toward a theory of market value of risky assets. Available at SSRN: https://ssrn.com/abstract=628187.

Trumpp, C., \& Guenther, T. (2015). Too little or too much? Exploring U-shaped relationships between corporate environmental performance and corporate financial performance. Business Strategy and the Environment, 26(1), 49-68.

Wang, R., Hogartaigh, C., \& Zijl, T. V. (2009). Measures of accounting conservatism: A construct validity perspective. Journal of Accounting Literature, 28, 165-203.

Watts, R., \& Zimmerman, J. (1986). Positive Accounting Theory. Upper Saddle River, NJ: Prentice Hall.

Watts, R.L. (2003). Conservatism in accounting part I: Explanations and implications. Accounting Horizons. 17, 207-221.

Wooldridge, J.M. (2002). Econometric Analysis of Cross Section and Panel Data. MIT Press, Cambridge, Massachusetts, London. 


\section{Table 1 : Variable Definitions}

\begin{tabular}{|c|c|}
\hline Variables & Definitions and measures \\
\hline COEC & Cost of equity capital estimated using the downside risk approach of Estrada (2000). \\
\hline CSCORE & $\begin{array}{l}\text { Firm's level of conditional conservatism obtained using the Khan and Watts (2009) } \\
\text { approach. }\end{array}$ \\
\hline CSCORE_RANK & The decile rank of the conservatism measure CSCORE. \\
\hline BNEWS & $\begin{array}{l}\text { Firm's level of conditional conservatism denoting the timeliness of bad news } \\
\text { recognition obtained using the Khan and Watts (2009) approach, computed as the } \\
\text { sum of CSCORE and GSCORE. }\end{array}$ \\
\hline BASU_metric & Firm's level of conditional conservatism obtained as in Gassen et al. (2013). \\
\hline SIZE & Firm's size computed as the natural logarithm of market value of equity. \\
\hline RTVOL & Stock return volatility, defined as the standard deviation of monthly stock returns. \\
\hline EARVOL & $\begin{array}{l}\text { Earnings variability, defined as the coefficient of variation of earnings using a five- } \\
\text { year rolling window. }\end{array}$ \\
\hline ROA & Firm's profitability, defined as net income divided by total assets. \\
\hline MTB & $\begin{array}{l}\text { Market-to-Book ratio computed as market value of equity divided by book value of } \\
\text { equity at the end of the fiscal year. }\end{array}$ \\
\hline LEV & $\begin{array}{l}\text { Firm's leverage defined as long term debt plus short term debt deflated by market } \\
\text { value of equity at the end of the fiscal year. }\end{array}$ \\
\hline GDPG & Annual growth in GDP. \\
\hline INFLATION & Inflation rate measured by the consumer price index (CPI) in a country. \\
\hline INVESPROT & $\begin{array}{l}\text { Strength of investor protection index scaled from } 0 \text { to } 10 \text {, with higher scores for } \\
\text { higher degree of investor protection from the Global Competitiveness Report 2015- } \\
2016 \text { by World Economic Forum). }\end{array}$ \\
\hline AUDIT & $\begin{array}{l}\text { Strength of auditing and reporting standards index scaled from } 1 \text { to } 7 \text {, with higher } \\
\text { scores for stronger financial auditing and reporting standards from the Global } \\
\text { Competitiveness Report 2015-2016 by World Economic Forum. }\end{array}$ \\
\hline
\end{tabular}


Table 2: List of countries

\begin{tabular}{|c|c|c|c|c|c|c|c|}
\hline Country & Code & Country & Code & Country & Code & Country & Code \\
\hline Argentina & (ARG) & Hungary & (HUN) & Morocco & (MAR) & South Africa & (ZAF) \\
\hline Brazil & (BRA) & India & (IND) & Nigeria & (NGR) & Sri Lanka & (LKA) \\
\hline Bulgaria & (BGR) & Indonesia & (IDN) & Pakistan & (PAK) & Taiwan & $(\mathbf{T W N})$ \\
\hline Chile & (CHL) & Israel & (ISR) & Peru & (PER) & Thailand & (THA) \\
\hline China & (CHN) & Jordan & (JOR) & Philippine & (PHL) & Tunisia & (TUN) \\
\hline Colombia & (COL) & Korea & (KOR) & Poland & (POL) & Turkey & (TUR) \\
\hline Czech Republic & (CZE) & Kuwait & $(\mathbf{K W T})$ & Qatar & (QAT) & United Arab Emirates & (ARE) \\
\hline Egypt & (EGY) & Lithuania & (LTU) & Russia & (RUS) & & \\
\hline Estonia & (EST) & Malaysia & (MYS) & Saudi Arabia & (KSA) & & \\
\hline Greece & (GRC) & Mexico & (MEX) & Slovenia & $(\mathbf{S V N})$ & & \\
\hline
\end{tabular}


Table 3: Distribution of firm-year observations by country and year

\begin{tabular}{|c|c|c|c|c|c|c|c|c|c|c|c|}
\hline Country & 2003 & 2004 & 2005 & 2006 & 2007 & 2009 & 2010 & 2011 & 2012 & Total firms & $\%$ of firms \\
\hline ARE & 0 & 0 & 0 & 3 & 7 & 15 & 18 & 19 & 31 & 93 & 0.21 \\
\hline ARG & 17 & 26 & 14 & 38 & 40 & 43 & 47 & 24 & 38 & 287 & 0.65 \\
\hline BGR & 0 & 0 & 0 & 0 & 0 & 44 & 44 & 28 & 40 & 156 & 0.35 \\
\hline BRA & 42 & 37 & 8 & 40 & 46 & 53 & 81 & 31 & 67 & 405 & 0.92 \\
\hline CHL & 56 & 51 & 41 & 59 & 65 & 70 & 70 & 43 & 70 & 525 & 1.19 \\
\hline CHN & 222 & 234 & 164 & 900 & 924 & 1,204 & 1,405 & 762 & 1,574 & 7,389 & 16.80 \\
\hline COL & 5 & 6 & 2 & 11 & 10 & 10 & 13 & 10 & 12 & 79 & 0.18 \\
\hline CZE & 4 & 4 & 1 & 4 & 5 & 5 & 5 & 5 & 5 & 38 & 0.09 \\
\hline EGY & 9 & 11 & 2 & 25 & 28 & 61 & 0 & 0 & 0 & 136 & 0.31 \\
\hline EST & 0 & 0 & 0 & 1 & 2 & 8 & 10 & 5 & 11 & 37 & 0.08 \\
\hline GRC & 143 & 155 & 51 & 174 & 181 & 188 & 175 & 41 & 138 & 1,246 & 2.83 \\
\hline HUN & 14 & 14 & 6 & 14 & 18 & 22 & 21 & 7 & 21 & 137 & 0.31 \\
\hline IDN & 70 & 91 & 24 & 114 & 128 & 100 & 133 & 63 & 172 & 895 & 2.03 \\
\hline IND & 211 & 257 & 49 & 344 & 420 & 1,012 & 1225 & 305 & 1,220 & 5,043 & 11.46 \\
\hline ISR & 43 & 56 & 28 & 92 & 92 & 264 & 288 & 136 & 284 & 1,283 & 2.92 \\
\hline JOR & 1 & 3 & 5 & 15 & 15 & 58 & 56 & 50 & 64 & 267 & 0.61 \\
\hline KOR & 481 & 511 & 72 & 639 & 699 & 1,124 & 1,188 & 229 & 1,296 & 6,239 & 14.18 \\
\hline KWT & 0 & 0 & 0 & 12 & 27 & 33 & 35 & 24 & 35 & 166 & 0.38 \\
\hline LKA & 10 & 8 & 3 & 16 & 20 & 81 & 88 & 62 & 111 & 399 & 0.91 \\
\hline LTU & 0 & 0 & 1 & 1 & 3 & 21 & 12 & 5 & 11 & 54 & 0.12 \\
\hline MAR & 6 & 9 & 7 & 15 & 15 & 28 & 34 & 29 & 38 & 181 & 0.41 \\
\hline MEX & 36 & 37 & 21 & 48 & 44 & 45 & 48 & 26 & 56 & 361 & 0.82 \\
\hline MYS & 333 & 386 & 183 & 479 & 545 & 642 & 656 & 332 & 644 & 4,200 & 9.55 \\
\hline NGA & 0 & 0 & 0 & 3 & 7 & 31 & 26 & 10 & 23 & 100 & 0.23 \\
\hline PAK & 47 & 59 & 12 & 66 & 65 & 29 & 36 & 63 & 141 & 518 & 1.18 \\
\hline PER & 16 & 18 & 7 & 30 & 27 & 39 & 37 & 14 & 28 & 216 & 0.49 \\
\hline PHL & 34 & 35 & 17 & 53 & 65 & 69 & 85 & 44 & 91 & 493 & 1.12 \\
\hline POL & 32 & 41 & 13 & 77 & 92 & 161 & 214 & 35 & 243 & 908 & 2.06 \\
\hline QAT & 0 & 0 & 0 & 3 & 7 & 13 & 16 & 16 & 18 & 73 & 0.17 \\
\hline RUS & 11 & 16 & 4 & 20 & 29 & 48 & 66 & 20 & 83 & 297 & 0.68 \\
\hline KSA & 0 & 0 & 0 & 33 & 41 & 66 & 73 & 55 & 85 & 353 & 0.80 \\
\hline SVN & 0 & 1 & 7 & 8 & 8 & 15 & 15 & 8 & 13 & 75 & 0.17 \\
\hline THA & 149 & 187 & 87 & 229 & 271 & 333 & 344 & 170 & 370 & 2,140 & 4.86 \\
\hline TUN & 0 & 0 & 0 & 1 & 1 & 19 & 19 & 17 & 16 & 73 & 0.17 \\
\hline TUR & 106 & 123 & 7 & 145 & 158 & 197 & 203 & 35 & 202 & 1,176 & 2.67 \\
\hline TWN & 332 & 628 & 256 & 847 & 949 & 1,054 & 1,102 & 452 & 1,172 & 6,792 & 15.44 \\
\hline ZAF & 120 & 130 & 27 & 131 & 135 & 145 & 172 & 116 & 189 & 1,165 & 2.65 \\
\hline Total firms & 2,550 & 3,134 & 1,119 & 4,690 & 5,189 & 7,350 & 8,060 & 3,291 & 8,612 & 43,995 & 100.00 \\
\hline
\end{tabular}


Table 4: Descriptive statistics

\begin{tabular}{|c|c|c|c|c|c|c|c|}
\hline \multicolumn{8}{|c|}{ Panel A: Country-level descriptive statistics } \\
\hline Country & Symbol & COEC & CSCORE & GDPG & INFLATION & INVESPROT & AUDIT \\
\hline Argentina & ARG & 29.81 & 0.018 & 5.91 & 9.09 & 4.70 & 4.02 \\
\hline Brazil & BRA & 33.08 & 0.008 & 3.90 & 7.51 & 5.30 & 4.82 \\
\hline Bulgaria & BGR & 28.89 & 0.013 & 0.28 & 2.93 & 6.00 & 4.31 \\
\hline Chile & $\mathrm{CHL}$ & 22.85 & 0.009 & 4.68 & 5.34 & 6.30 & 5.43 \\
\hline China & $\mathrm{CHN}$ & 31.26 & 0.008 & 9.69 & 4.49 & 4.96 & 4.41 \\
\hline Colombia & $\mathrm{COL}$ & 27.25 & 0.011 & 4.89 & 4.94 & 7.06 & 4.47 \\
\hline Czech Republic & CZE & 23.14 & 0.008 & 2.75 & 1.59 & 5.00 & 5.01 \\
\hline Egypt & EGY & 36.92 & -0.003 & 5.42 & 8.57 & 4.75 & 4.80 \\
\hline Estonia & EST & 30.56 & 0.035 & 3.27 & 2.94 & 5.87 & 5.59 \\
\hline Greece & GRC & 38.65 & 0.014 & 1.90 & 2.35 & 4.30 & 4.90 \\
\hline Hungary & HUN & 30.21 & 0.016 & 1.24 & 3.89 & 4.30 & 5.26 \\
\hline India & IND & 37.18 & 0.010 & 8.19 & 7.25 & 6.00 & 5.35 \\
\hline Indonesia & IDN & 34.85 & 0.018 & 5.68 & 7.52 & 5.51 & 4.40 \\
\hline Israel & ISR & 31.61 & 0.014 & 3.48 & 2.60 & 8.30 & 5.58 \\
\hline Jordan & JOR & 19.70 & 0.018 & 3.98 & 5.52 & 4.30 & 5.21 \\
\hline Korea, Republic of & KOR & 36.42 & 0.015 & 3.79 & 2.29 & 5.30 & 4.75 \\
\hline Kuwait & KWT & 22.48 & 0.008 & 3.66 & 6.14 & 6.30 & 4.89 \\
\hline Lithuania & LTU & 31.66 & 0.003 & 1.96 & 2.24 & 5.30 & 5.07 \\
\hline Malaysia & MYS & 28.51 & 0.021 & 4.96 & 3.98 & 8.70 & 5.57 \\
\hline Mexico & MEX & 28.05 & 0.010 & 2.87 & 5.26 & 5.56 & 4.71 \\
\hline Morocco & MAR & 20.99 & 0.017 & 4.33 & 0.83 & 4.30 & 4.16 \\
\hline Nigeria & NGA & 36.35 & 0.007 & 6.39 & 5.93 & 5.70 & 3.92 \\
\hline Pakistan & PAK & 32.23 & 0.023 & 4.41 & 7.39 & 6.30 & 4.53 \\
\hline Peru & PER & 31.38 & 0.010 & 5.78 & 3.96 & 6.57 & 4.81 \\
\hline Philippine & PHL & 30.85 & 0.018 & 5.46 & 3.59 & 4.30 & 4.89 \\
\hline Poland & POL & 35.44 & 0.014 & 3.62 & 2.62 & 5.98 & 4.93 \\
\hline Qatar & QAT & 16.03 & 0.007 & 9.17 & 6.28 & 5.00 & 5.72 \\
\hline Russia & RUS & 34.65 & 0.007 & 4.25 & 7.94 & 5.08 & 3.86 \\
\hline Saudi Arabia & KSA & 24.68 & 0.008 & 4.09 & 6.07 & 6.39 & 5.27 \\
\hline Slovenia & SVN & 21.91 & 0.033 & 1.47 & 1.69 & 6.39 & 5.00 \\
\hline South Africa & $\mathrm{ZAF}$ & 31.79 & 0.016 & 3.13 & 6.56 & 8.00 & 5.87 \\
\hline Sri-Lanka & LKA & 33.81 & 0.020 & 7.29 & 7.60 & 5.30 & 5.10 \\
\hline Taiwan & TWN & 29.27 & 0.018 & 4.71 & 2.02 & 5.30 & 5.33 \\
\hline Thailand & THA & 29.82 & 0.019 & 4.86 & 2.84 & 6.97 & 5.02 \\
\hline Tunisia & TUN & 19.06 & 0.017 & 2.35 & 3.97 & 5.04 & 4.93 \\
\hline Turkey & TUR & 40.06 & 0.017 & 5.46 & 7.10 & 5.52 & 4.58 \\
\hline United Arab Emirates & ARE & 21.30 & 0.010 & 3.52 & 5.32 & 4.30 & 5.36 \\
\hline
\end{tabular}


Table 4 (Continued)

Panel B: Descriptive statistics for main variables

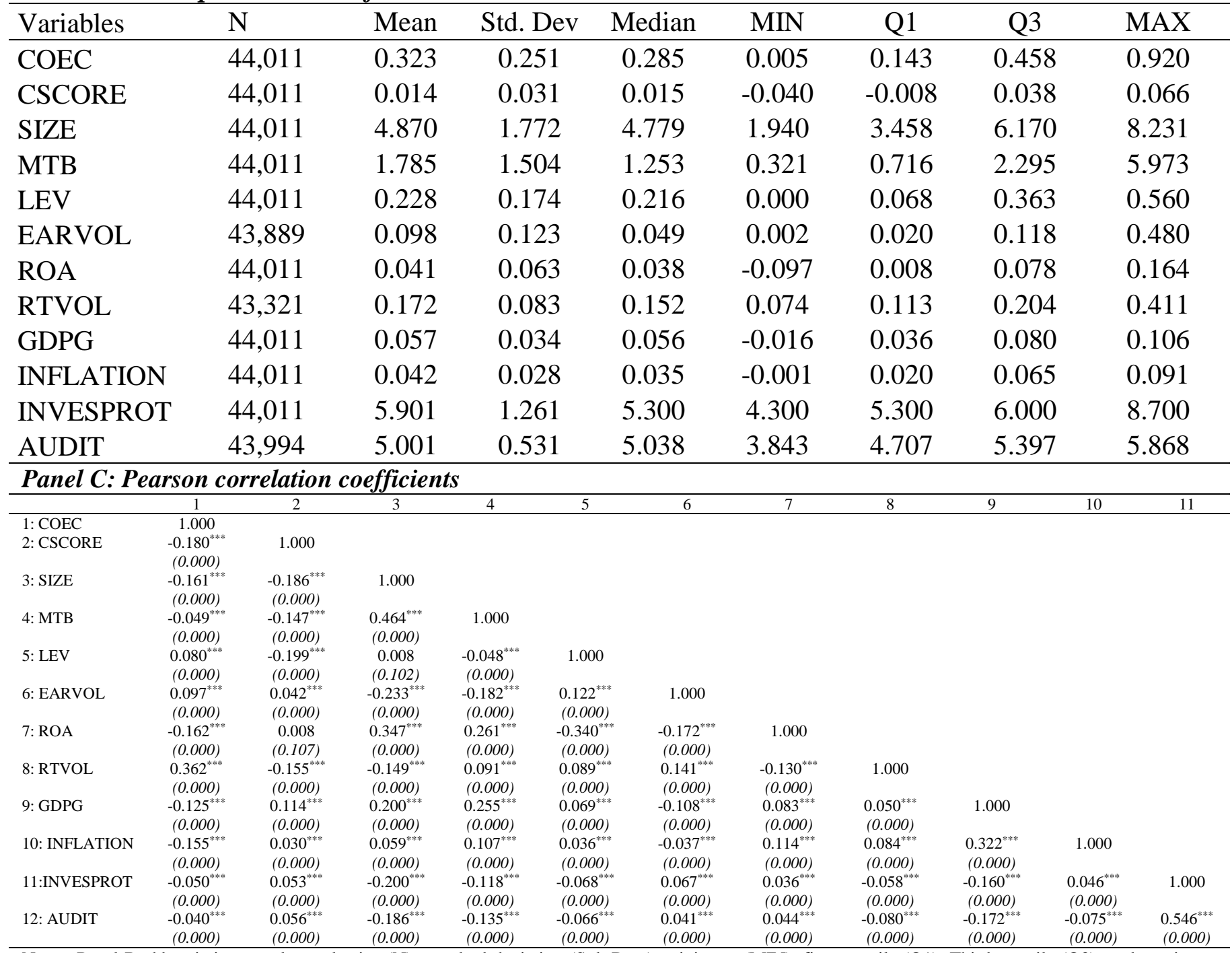

Notes: Panel B abbreviations are 1 sample size (N), standard deviation (Std. Dev.), minimum (MIN), first quartile (Q1), Third quartile (Q3), and maximum (MAX). See Table 1 for variable definitions. ${ }^{* * *},{ }^{* *}$, and ${ }^{*}$ represent significance levels of 1,5 , and $10 \%$, respectively 

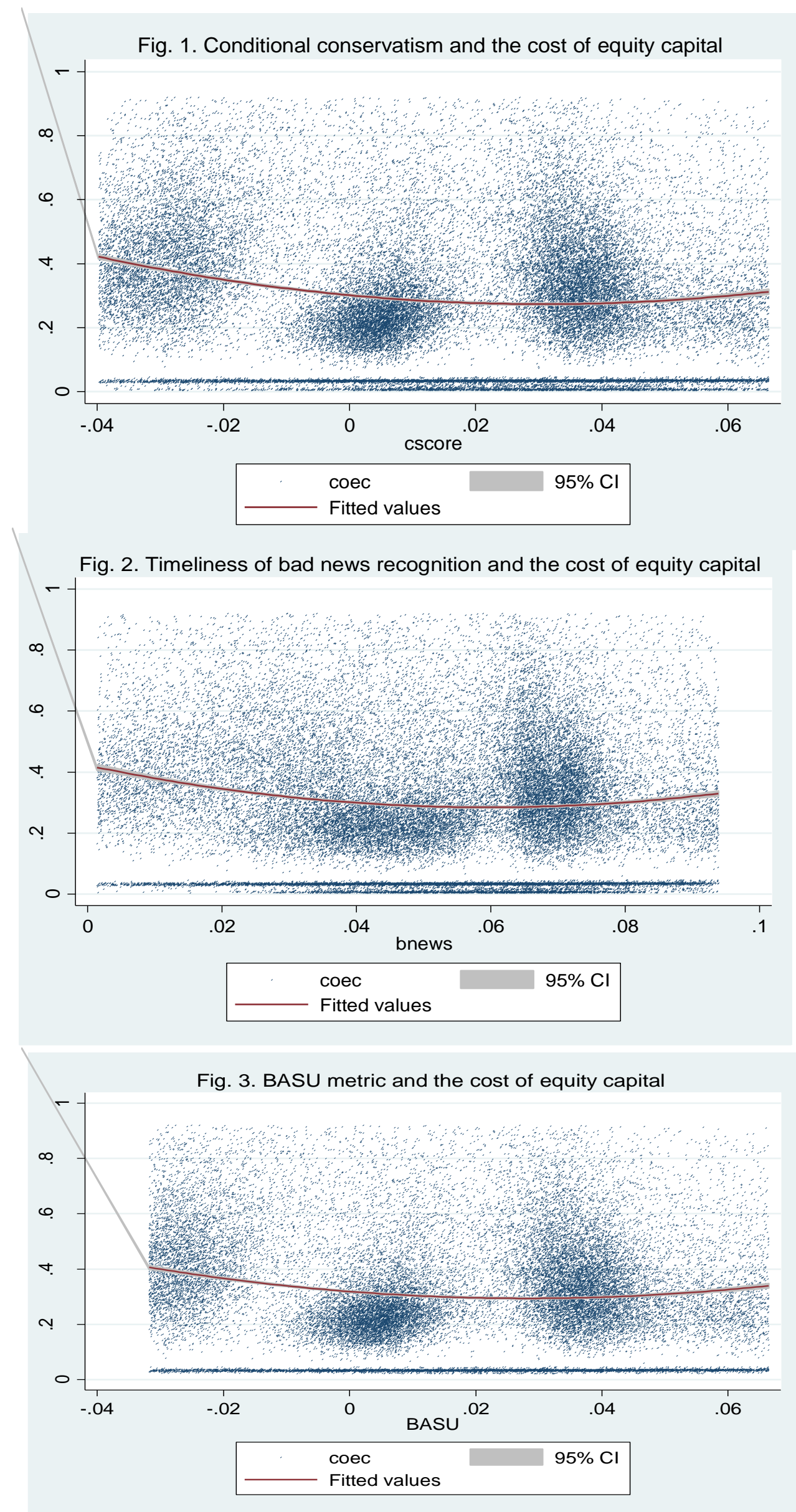
Table 5: The appropriate $U$ test for the relationship between conditional conservatism and the cost of equity capital

Dependent variable: Cost of equity capital: COEC

\begin{tabular}{|c|c|c|c|c|}
\hline & & $\begin{array}{c}\text { Conservatism } \\
= \\
\text { CSCORE }\end{array}$ & $\begin{array}{c}\text { Conservatism } \\
= \\
\text { BNEWS }\end{array}$ & $\begin{array}{c}\text { Conservatism } \\
= \\
\text { BASU_metric }\end{array}$ \\
\hline Conservatism & $\hat{\beta}=$ & $\begin{array}{c}-1.770^{* * *} \\
(-4.22)\end{array}$ & $\begin{array}{c}-4.269^{* * * *} \\
(-3.88)\end{array}$ & $\begin{array}{c}-2.117^{* * * *} \\
(-4.63)\end{array}$ \\
\hline Conservatism² & $\hat{\gamma}=$ & $\begin{array}{c}23.202^{* * *} \\
(5.52)\end{array}$ & $\begin{array}{l}31.501^{* * * *} \\
(5.05)\end{array}$ & $\begin{array}{l}21.771^{* * * *} \\
(4.40)\end{array}$ \\
\hline Slope at $X_{l}$ & $\hat{\beta}+2 \hat{\gamma} x_{l}=$ & $\begin{array}{c}-3.612^{* * *} \\
(-5.08)\end{array}$ & $\begin{array}{c}-4.18^{* * *} \\
(-3.86)\end{array}$ & $\begin{array}{c}-4.708^{* * *} \\
(-4.65)\end{array}$ \\
\hline Slope at $X_{h}$ & $\hat{\beta}+2 \hat{\gamma} x_{h}=$ & $\begin{array}{l}1.311^{* * * *} \\
(3.74)\end{array}$ & $\begin{array}{l}1.647^{* * * *} \\
(4.78)\end{array}$ & $\begin{array}{l}1.337^{* * * *} \\
(2.97)\end{array}$ \\
\hline Appropriate $\mathrm{U}$ test & & $\begin{array}{l}3.74^{* * *} \\
{[0.000]}\end{array}$ & $\begin{array}{l}3.86^{* * * *} \\
{[0.000]}\end{array}$ & $\begin{array}{l}2.97^{* * *} \\
{[0.002]}\end{array}$ \\
\hline Extreme point & $-\frac{\widehat{\beta}}{2 \widehat{\gamma}}=$ & 0.0381 & 0.0677 & 0.0486 \\
\hline $\begin{array}{l}95 \% \text { confidence interval, } \\
\text { Fieller method }\end{array}$ & & {$[0.026 ; 0.050]$} & {$[0.051 ; 0.078]$} & {$[0.0380 ; 0.0638]$} \\
\hline
\end{tabular}


Table 6: OLS analyses of the association between conditional conservatism and the cost of equity capital

\begin{tabular}{|c|c|c|c|c|c|c|}
\hline \multicolumn{7}{|c|}{ Panel A: Using raw values of CSCORE } \\
\hline \multirow{3}{*}{ Independent variables } & \multicolumn{6}{|c|}{ Dependent variable: COEC } \\
\hline & \multicolumn{3}{|c|}{ Linear relationship } & \multicolumn{3}{|c|}{ Quadratic relationship } \\
\hline & $(1)$ & $(2)$ & $(3)$ & (1) & $(2)$ & (3) \\
\hline \multirow[t]{2}{*}{ Constant } & $0.645^{* * *}$ & $0.565^{* * *}$ & $0.598^{* * *}$ & $0.661^{* * *}$ & $0.578^{* * *}$ & $0.609^{* * *}$ \\
\hline & $(41.77)$ & $(42.27)$ & $(28.96)$ & $(42.38)$ & $(42.78)$ & $(29.42)$ \\
\hline \multirow[t]{2}{*}{ CSCORE } & -0.003 & $-0.130^{* * * *}$ & $-0.111^{* * *}$ & $-0.872^{* * *}$ & $-0.698^{* * * *}$ & $-0.669^{* * *}$ \\
\hline & $(-0.10)$ & $(-5.26)$ & $(-4.43)$ & $(-7.10)$ & $(-6.99)$ & $(-6.71)$ \\
\hline \multirow[t]{2}{*}{$\mathrm{CSCORE}^{2}$} & & & & $0.080^{* * *}$ & $0.052^{* * *}$ & $0.051^{* * *}$ \\
\hline & & & & $(7.29)$ & $(5.93)$ & $(5.84)$ \\
\hline \multirow[t]{2}{*}{ SIZE } & & $-0.009^{* * *}$ & $-0.008^{* * *}$ & & $-0.009^{* * *}$ & $-0.008^{* * *}$ \\
\hline & & $(-16.47)$ & $(-15.44)$ & & $(-16.66)$ & $(-15.64)$ \\
\hline \multirow[t]{2}{*}{ MTB } & & $0.004^{* * * *}$ & $0.004^{* * *}$ & & $0.004^{* * *}$ & $0.003^{* * *}$ \\
\hline & & $(7.35)$ & $(7.26)$ & & $(6.35)$ & (6.27) \\
\hline \multirow[t]{2}{*}{ LEV } & & $0.007^{*}$ & $0.007^{*}$ & & 0.007 & 0.007 \\
\hline & & (1.73) & (1.69) & & $(1.65)$ & (1.62) \\
\hline \multirow[t]{2}{*}{ EARVOL } & & $0.043^{* * *}$ & $0.044^{* * * *}$ & & $0.043^{* * *}$ & $0.044^{* * *}$ \\
\hline & & $(7.21)$ & (7.47) & & (7.14) & $(7.40)$ \\
\hline \multirow[t]{2}{*}{ ROA } & & $-0.228^{* * * *}$ & $-0.227^{* * *}$ & & $-0.223^{* * * *}$ & $-0.222^{* * *}$ \\
\hline & & $(-17.50)$ & $(-17.49)$ & & $(-17.12)$ & $(-17.12)$ \\
\hline \multirow[t]{2}{*}{ RTVOL } & & $0.834^{* * *}$ & $0.836^{* * *}$ & & $0.834^{* * *}$ & $0.836^{* * *}$ \\
\hline & & $(65.85)$ & (66.18) & & (65.89) & (66.22) \\
\hline \multirow[t]{2}{*}{ GDPG } & & & $-0.163^{* * *}$ & & & $-0.158^{* * *}$ \\
\hline & & & $(-4.51)$ & & & $(-4.38)$ \\
\hline \multirow[t]{2}{*}{ INFLATION } & & & 0.035 & & & 0.039 \\
\hline & & & $(0.94)$ & & & $(1.04)$ \\
\hline \multirow[t]{2}{*}{ INVESPROT } & & & $0.017^{* * * *}$ & & & $0.017^{* * * *}$ \\
\hline & & & (6.03) & & & (6.06) \\
\hline \multirow[t]{2}{*}{ AUDIT } & & & $-0.019^{* * * *}$ & & & $-0.019^{* * *}$ \\
\hline & & & $(-9.17)$ & & & $(-9.14)$ \\
\hline Industry dummies & Yes & Yes & Yes & Yes & Yes & Yes \\
\hline Country dummies & Yes & Yes & Yes & Yes & Yes & Yes \\
\hline Year dummies & Yes & Yes & Yes & Yes & Yes & Yes \\
\hline$N$ & 44,011 & 43,229 & 43,212 & 44,011 & 43,229 & 43,212 \\
\hline$R^{2}(\%)$ & 64.2 & 73.5 & 73.6 & 64.2 & 73.6 & 73.6 \\
\hline $\begin{array}{l}\text { Notes: The t-statistics in par } \\
\text { conservatism measure (CSCO } \\
\text { test where sign is predicted; } t\end{array}$ & able I for & able definit & $\begin{array}{l}\text { rd errors at the } \\
* * \text { and * repres }\end{array}$ & $\begin{array}{l}\text { level. CSCOR } \\
\text { nificance level }\end{array}$ & $\begin{array}{l}\text { the quadratic } \\
1 \text { and } 10 \% \text {, resp }\end{array}$ & $\begin{array}{l}\mathrm{n} \text { of conditional } \\
\text { ively (one-tailed }\end{array}$ \\
\hline
\end{tabular}


Table 6 (Continued)

Panel B: Using deciles rank of CSCORE

\begin{tabular}{|c|c|c|c|c|c|c|}
\hline \multirow{3}{*}{ Independent variables } & \multicolumn{6}{|c|}{ Dependent variable: COEC } \\
\hline & \multicolumn{3}{|c|}{ Linear relationship } & \multicolumn{3}{|c|}{ Quadratic relationship } \\
\hline & (1) & $(2)$ & (3) & $(1)$ & $(2)$ & (3) \\
\hline \multirow[t]{2}{*}{ Constant } & $0.645^{* * *}$ & $0.565^{* * *}$ & $0.598^{* * *}$ & $0.661^{* * *}$ & $0.578^{* * *}$ & $0.609^{* * *}$ \\
\hline & $(41.77)$ & $(42.27)$ & $(28.97)$ & $(42.37)$ & $(42.78)$ & $(29.42)$ \\
\hline \multirow[t]{2}{*}{ CSCORE_RANK } & -0.000 & $-0.001^{* * *}$ & $-0.001^{* * *}$ & $-0.009^{* * * *}$ & $-0.007^{* * *}$ & $-0.007^{* * *}$ \\
\hline & $(-0.09)$ & $(-5.24)$ & $(-4.42)$ & $(-7.10)$ & $(-6.99)$ & $(-6.70)$ \\
\hline \multirow[t]{2}{*}{ CSCORE_RANK ${ }^{2}$} & & & & $0.001^{* * *}$ & $0.001^{* * *}$ & $0.001^{* * *}$ \\
\hline & & & & $(7.29)$ & $(5.92)$ & $(5.83)$ \\
\hline \multirow[t]{2}{*}{ SIZE } & & $-0.009^{* * *}$ & $-0.008^{* * *}$ & & $-0.009^{* * *}$ & $-0.008^{* * *}$ \\
\hline & & $(-16.46)$ & $(-15.44)$ & & $(-16.66)$ & $(-15.64)$ \\
\hline \multirow[t]{2}{*}{ MTB } & & $0.004^{* * *}$ & $0.004^{* * *}$ & & $0.004^{* * *}$ & $0.003^{* * *}$ \\
\hline & & $(7.34)$ & $(7.25)$ & & $(6.34)$ & $(6.26)$ \\
\hline \multirow[t]{2}{*}{ LEV } & & $0.007^{*}$ & $0.007^{*}$ & & 0.007 & 0.007 \\
\hline & & $(1.72)$ & (1.69) & & $(1.64)$ & $(1.61)$ \\
\hline \multirow[t]{2}{*}{ EARVOL } & & $0.043^{* * *}$ & $0.044^{* * * *}$ & & $0.042^{* * * *}$ & $0.044^{* * *}$ \\
\hline & & (7.19) & $(7.45)$ & & (7.12) & (7.38) \\
\hline \multirow[t]{2}{*}{ ROA } & & $-0.228^{* * *}$ & $-0.227^{* * *}$ & & $-0.223^{* * *}$ & $-0.222^{* * *}$ \\
\hline & & $(-17.50)$ & $(-17.49)$ & & $(-17.12)$ & $(-17.12)$ \\
\hline \multirow[t]{2}{*}{ RTVOL } & & $0.834^{* * *}$ & $0.836^{* * *}$ & & $0.834^{* * *}$ & $0.836^{* * *}$ \\
\hline & & $(65.85)$ & (66.18) & & $(65.89)$ & $(66.21)$ \\
\hline \multirow[t]{2}{*}{ GDPG } & & & $-0.162^{* * *}$ & & & $-0.157^{* * *}$ \\
\hline & & & $(-4.49)$ & & & $(-4.36)$ \\
\hline \multirow[t]{2}{*}{ INFLATION } & & & 0.035 & & & 0.039 \\
\hline & & & $(0.93)$ & & & $(1.02)$ \\
\hline \multirow[t]{2}{*}{ INVPROT } & & & $0.017^{* * *}$ & & & $0.017^{* * *}$ \\
\hline & & & $(6.04)$ & & & (6.07) \\
\hline \multirow[t]{2}{*}{ AUDIT } & & & $-0.019^{* * *}$ & & & $-0.019^{* * *}$ \\
\hline & & & $(-9.18)$ & & & $(-9.16)$ \\
\hline Industry dummies & Yes & Yes & Yes & Yes & Yes & Yes \\
\hline Country dummies & Yes & Yes & Yes & Yes & Yes & Yes \\
\hline Year dummies & Yes & Yes & Yes & Yes & Yes & Yes \\
\hline$N$ & 44,011 & 43,229 & 43,212 & 44,011 & 43,229 & 43,212 \\
\hline$R^{2}(\%)$ & 64.2 & 73.5 & 73.6 & 64.2 & 73.6 & 73.6 \\
\hline
\end{tabular}

Notes: This table reports pooled OLS results of the effect of accounting conservatism on the cost of equity capital. The t-statistics (in parentheses) are estimated with clustered standard errors at the firm level following Petersen (2009). CSCORE_RANK ${ }^{2}$ is the quadratic term of the CSCORE_RANK variable as defined in Table 1 . See Table 1 for other variable definitions. ***, and * represent significance levels of 1 and $10 \%$, respectively (onetailed test where sign is predicted; two-tailed test otherwise). 
Table 7: OLS analyses of the association between conditional conservatism and the cost of equity capital using alternative measures of conservatism

\begin{tabular}{|c|c|c|}
\hline \multirow{4}{*}{ Independent variables } & \multicolumn{2}{|c|}{ Dependent variable: COEC } \\
\hline & Conservatism & Conservatism \\
\hline & $=$ & $=$ \\
\hline & BNEWS & BASU_metric \\
\hline \multirow[t]{2}{*}{ Constant } & $0.614^{* * *}$ & $0.608^{* * *}$ \\
\hline & $(29.48)$ & $(29.33)$ \\
\hline \multirow[t]{2}{*}{ Conservatism } & $-0.699^{* * *}$ & $-0.612^{* * * *}$ \\
\hline & $(-6.92)$ & $(-6.14)$ \\
\hline \multirow[t]{2}{*}{ Conservatism $^{2}$} & $0.052^{* * *}$ & $0.044^{* * *}$ \\
\hline & $(5.96)$ & $(5.10)$ \\
\hline \multirow[t]{2}{*}{ SIZE } & $-0.008^{* * *}$ & $-0.008^{* * * *}$ \\
\hline & $(-15.76)$ & $(-15.67)$ \\
\hline \multirow[t]{2}{*}{ MTB } & $0.003^{* * *}$ & $0.004^{* * *}$ \\
\hline & $(4.95)$ & $(6.46)$ \\
\hline \multirow[t]{2}{*}{ LEV } & $0.009^{* *}$ & 0.006 \\
\hline & $(2.08)$ & $(1.51)$ \\
\hline \multirow[t]{2}{*}{ EARVOL } & $0.044^{* * *}$ & $0.044^{* * *}$ \\
\hline & $(7.39)$ & $(7.41)$ \\
\hline \multirow[t]{2}{*}{ ROA } & $-0.223^{* * *}$ & $-0.223^{* * *}$ \\
\hline & $(-17.23)$ & $(-17.14)$ \\
\hline \multirow[t]{2}{*}{ RTVOL } & $0.836^{* * *}$ & $0.836^{* * *}$ \\
\hline & $(66.33)$ & $(66.20)$ \\
\hline \multirow[t]{2}{*}{ GDPG } & $-0.155^{* * *}$ & $-0.159^{* * * *}$ \\
\hline & $(-4.31)$ & $(-4.41)$ \\
\hline \multirow[t]{2}{*}{ INFLATION } & 0.039 & 0.036 \\
\hline & $(1.02)$ & $(0.95)$ \\
\hline \multirow[t]{2}{*}{ INVESPROT } & $0.017^{* * * *}$ & $0.017^{* * *}$ \\
\hline & (6.13) & $(6.06)$ \\
\hline \multirow[t]{2}{*}{ AUDIT } & $-0.019^{* * *}$ & $-0.019^{* * * *}$ \\
\hline & $(-9.54)$ & $(-9.10)$ \\
\hline Industry dummies & Yes & Yes \\
\hline Country dummies & Yes & Yes \\
\hline Year dummies & Yes & Yes \\
\hline$N$ & 43,212 & 43,212 \\
\hline$R^{2}(\%)$ & 73.60 & 73.60 \\
\hline
\end{tabular}


Table 8: Accounting conservatism and the cost of equity capital: Excluding some countries with higher sample size

\begin{tabular}{|c|c|c|c|c|c|}
\hline \multirow{3}{*}{$\begin{array}{l}\text { Independent } \\
\text { variables }\end{array}$} & \multicolumn{5}{|c|}{ Dependent variable: COEC } \\
\hline & $\begin{array}{c}\text { Excluding } \\
\text { Korea }\end{array}$ & $\begin{array}{c}\text { Excluding } \\
\text { China }\end{array}$ & $\begin{array}{c}\text { Excluding } \\
\text { Taiwan }\end{array}$ & $\begin{array}{l}\text { Excluding } \\
\text { India }\end{array}$ & Excluding All \\
\hline & $(1)$ & $(2)$ & (3) & (4) & $(5)$ \\
\hline \multirow[t]{2}{*}{ Constant } & $0.587^{* * *}$ & $0.655^{* * *}$ & $0.599^{* * *}$ & $0.644^{* * *}$ & $0.785^{* * *}$ \\
\hline & $(26.12)$ & $(27.48)$ & $(28.83)$ & $(30.34)$ & $(21.34)$ \\
\hline \multirow[t]{2}{*}{ CSCORE } & $-0.787^{* * *}$ & $-0.764^{* * *}$ & $-0.613^{* * *}$ & $-0.594^{* * *}$ & $-0.829^{* * *}$ \\
\hline & $(-7.59)$ & $(-6.63)$ & $(-5.66)$ & $(-5.43)$ & $(-4.98)$ \\
\hline \multirow[t]{2}{*}{$\mathrm{CSCORE}^{2}$} & $0.062^{* * *}$ & $0.053^{* * *}$ & $0.047^{* * *}$ & $0.045^{* * *}$ & $0.061^{* * *}$ \\
\hline & $(6.76)$ & $(5.29)$ & $(4.89)$ & $(4.63)$ & (4.19) \\
\hline \multirow[t]{2}{*}{ SIZE } & $-0.009^{* * *}$ & $-0.008^{* * *}$ & $-0.010^{* * *}$ & $-0.007^{* * *}$ & $-0.010^{* * *}$ \\
\hline & $(-16.39)$ & $(-14.33)$ & $(-16.37)$ & $(-12.40)$ & $(-11.59)$ \\
\hline \multirow[t]{2}{*}{ MTB } & $0.002^{* * *}$ & $0.006^{* * *}$ & $0.003^{* * *}$ & $0.005^{* * *}$ & $0.003^{* * *}$ \\
\hline & $(3.26)$ & $(8.20)$ & $(4.67)$ & $(7.84)$ & $(3.36)$ \\
\hline \multirow[t]{2}{*}{ LEV } & 0.006 & 0.007 & 0.008 & 0.005 & 0.012 \\
\hline & $(1.28)$ & $(1.55)$ & $(1.83)$ & (1.16) & $(1.83)$ \\
\hline \multirow[t]{2}{*}{ EARVOL } & $0.045^{* * * *}$ & $0.043^{* * *}$ & $0.040^{* * *}$ & $0.045^{* * *}$ & $0.038^{* * * *}$ \\
\hline & (6.69) & $(6.86)$ & $(6.31)$ & $(6.96)$ & $(4.20)$ \\
\hline \multirow[t]{2}{*}{ ROA } & $-0.207^{* * * *}$ & $-0.246^{* * *}$ & $-0.210^{* * * *}$ & $-0.231^{* * *}$ & $-0.226^{* * *}$ \\
\hline & $(-14.91)$ & $(-17.43)$ & $(-14.49)$ & $(-16.74)$ & $(-11.18)$ \\
\hline \multirow[t]{2}{*}{ RTVOL } & $0.839^{* * *}$ & $0.824^{* * *}$ & $0.807^{* * *}$ & $0.857^{* * *}$ & $0.804^{* * * *}$ \\
\hline & $(60.53)$ & $(60.93)$ & $(61.96)$ & (61.04) & $(43.07)$ \\
\hline \multirow[t]{2}{*}{ GDPG } & $-0.186^{* * *}$ & -0.024 & -0.059 & $-0.342^{* * *}$ & $-0.283^{* * *}$ \\
\hline & $(-5.11)$ & $(-0.64)$ & $(-1.36)$ & $(-8.95)$ & $(-4.93)$ \\
\hline \multirow[t]{2}{*}{ INFLATION } & 0.030 & $0.112^{* * *}$ & -0.057 & 0.070 & $0.227^{* * * *}$ \\
\hline & $(0.76)$ & $(2.34)$ & $(-1.40)$ & $(1.78)$ & $(3.50)$ \\
\hline \multirow[t]{2}{*}{ INVESPROT } & $0.020^{* * * *}$ & $0.009^{* * *}$ & $0.014^{* * *}$ & $0.018^{* * *}$ & $0.014^{* * *}$ \\
\hline & (6.99) & (3.12) & (4.71) & (6.31) & (4.17) \\
\hline \multirow[t]{2}{*}{ AUDIT } & $-0.012^{* * *}$ & $-0.021^{* * *}$ & $-0.013^{* * *}$ & $-0.029^{* * *}$ & $-0.045^{* * *}$ \\
\hline & $(-4.96)$ & $(-7.13)$ & $(-6.33)$ & $(-13.47)$ & $(-7.29)$ \\
\hline Country dummies & Yes & Yes & Yes & Yes & Yes \\
\hline Industry dummies & Yes & Yes & Yes & Yes & Yes \\
\hline Year dummies & Yes & Yes & Yes & Yes & Yes \\
\hline$N$ & 36,981 & 35,828 & 36,425 & 38,233 & 17,831 \\
\hline$R^{2}(\%)$ & 74.7 & 72.5 & 72.5 & 73.8 & 71.8 \\
\hline $\begin{array}{l}\text { Notes: The t-statistics (in } \\
\text { of conditional conservatis } \\
\text { (one-tailed test where sig }\end{array}$ & licted; two-tai & $\begin{array}{l}\text { lustered standa } \\
1 \text { for other va } \\
\text { rwise). }\end{array}$ & firm level & $\operatorname{sen}(2009)$. & $\begin{array}{l}\mathrm{E}^{2} \text { is the quadratic te } \\
1 \text { and } 5 \% \text {, respectiv }\end{array}$ \\
\hline
\end{tabular}


Table 9: Conditional conservatism and the cost of equity capital: Panel regression

\begin{tabular}{|c|c|c|c|c|c|c|}
\hline \multirow[b]{3}{*}{$\begin{array}{l}\text { Independent } \\
\text { variables }\end{array}$} & \multicolumn{6}{|c|}{ Dependent variable: COEC } \\
\hline & \multicolumn{2}{|c|}{ Conservatism $=$ CSCORE } & \multicolumn{2}{|c|}{ Conservatism $=$ BNEWS } & \multicolumn{2}{|c|}{ Conservatism $=$ BASU metric } \\
\hline & $\mathrm{FE}$ & GLS_RE & $\mathrm{FE}$ & GLS_RE & $\mathrm{FE}$ & GLS_RE \\
\hline \multirow[t]{2}{*}{ Constant } & $0.725^{* * * *}$ & $0.615^{* * *}$ & $0.725^{* * * *}$ & $0.618^{* * * *}$ & $0.724^{* * * *}$ & $0.614^{* * * *}$ \\
\hline & $(30.96)$ & $(26.50)$ & $(30.96)$ & $(26.60)$ & $(30.91)$ & $(26.46)$ \\
\hline \multirow[t]{2}{*}{ Conservatism } & $-0.350^{* * *}$ & $-0.646^{* * *}$ & $-0.228^{*}$ & $-0.587^{* * *}$ & $-0.310^{* * *}$ & $-0.595^{* * *}$ \\
\hline & $(-2.80)$ & $(-6.28)$ & $(-1.66)$ & $(-5.69)$ & $(-2.48)$ & $(-5.80)$ \\
\hline \multirow[t]{2}{*}{ Conservatism ${ }^{2}$} & $0.025^{* *}$ & $0.049^{* * *}$ & 0.012 & $0.041^{* * *}$ & 0.020 & $0.043^{* * * *}$ \\
\hline & $(2.19)$ & (5.37) & $(0.95)$ & $(4.55)$ & (1.79) & (4.77) \\
\hline \multirow[t]{2}{*}{ SIZE } & $-0.027^{* * * *}$ & $-0.009^{* * *}$ & $-0.027^{* * *}$ & $-0.009^{* * *}$ & $-0.027^{* * * *}$ & $-0.009^{* * *}$ \\
\hline & $(-14.95)$ & $(-16.45)$ & $(-14.87)$ & $(-16.32)$ & $(-14.93)$ & $(-16.44)$ \\
\hline \multirow[t]{2}{*}{ МТB } & $0.006^{* * * *}$ & $0.003^{* * * *}$ & $0.006^{* * * *}$ & $0.003^{* * * *}$ & $0.006^{* * * *}$ & $0.004^{* * * *}$ \\
\hline & $(6.14)$ & $(6.14)$ & $(5.55)$ & $(4.98)$ & $(6.16)$ & $(6.32)$ \\
\hline \multirow[t]{2}{*}{ LEV } & $0.016^{*}$ & 0.008 & $0.018^{* * *}$ & $0.010^{* *}$ & $0.015^{*}$ & $0.008^{*}$ \\
\hline & $(1.74)$ & $(1.84)$ & (1.99) & $(2.35)$ & $(1.71)$ & $(1.76)$ \\
\hline \multirow[t]{2}{*}{ EARVOL } & -0.006 & $0.038^{* * * *}$ & -0.006 & $0.038^{* * * *}$ & -0.006 & $0.038^{* * * *}$ \\
\hline & $(-0.85)$ & $(6.76)$ & $(-0.83)$ & (6.79) & $(-0.84)$ & (6.78) \\
\hline \multirow[t]{2}{*}{ ROA } & $-0.042^{* *}$ & $-0.210^{* * * *}$ & $-0.042^{* * *}$ & $-0.211^{* * * *}$ & $-0.043^{* *}$ & $-0.210^{* * * *}$ \\
\hline & $(-2.29)$ & $(-16.68)$ & $(-2.28)$ & $(-16.82)$ & $(-2.30)$ & $(-16.70)$ \\
\hline \multirow[t]{2}{*}{ RTVOL } & $0.698^{* * *}$ & $0.826^{* * *}$ & $0.699^{* * * *}$ & $0.827^{* * * *}$ & $0.698^{* * *}$ & $0.826^{* * * *}$ \\
\hline & $(58.81)$ & (95.82) & $(58.88)$ & (95.89) & $(58.81)$ & $(95.81)$ \\
\hline \multirow[t]{2}{*}{ GDPG } & $-0.149^{* * *}$ & $-0.160^{* * * *}$ & $-0.147^{* * *}$ & $-0.158^{* * *}$ & $-0.151^{* * * *}$ & $-0.161^{* * *}$ \\
\hline & $(-3.83)$ & $(-4.36)$ & $(-3.77)$ & $(-4.30)$ & $(-3.86)$ & $(-4.39)$ \\
\hline \multirow[t]{2}{*}{ INFLATION } & 0.030 & 0.037 & 0.026 & 0.035 & 0.028 & 0.034 \\
\hline & $(0.76)$ & $(1.01)$ & $(0.66)$ & $(0.94)$ & $(0.71)$ & $(0.93)$ \\
\hline \multirow[t]{2}{*}{ INVESPROT } & $0.014^{* * *}$ & $0.017^{* * *}$ & $0.014^{* * * *}$ & $0.017^{* * *}$ & $0.014^{* * * *}$ & $0.017^{* * *}$ \\
\hline & (4.34) & (5.99) & $(4.36)$ & (6.04) & (4.35) & (5.98) \\
\hline \multirow[t]{2}{*}{ AUDIT } & $-0.016^{* * *}$ & $-0.018^{* * *}$ & $-0.016^{* * *}$ & $-0.019^{* * *}$ & $-0.016^{* * *}$ & $-0.018^{* * *}$ \\
\hline & $(-6.20)$ & $(-8.03)$ & $(-6.42)$ & $(-8.36)$ & $(-6.15)$ & $(-7.99)$ \\
\hline Country dummies & Yes & Yes & Yes & Yes & Yes & Yes \\
\hline Industry dummies & Yes & Yes & Yes & Yes & Yes & Yes \\
\hline Year dummies & Yes & Yes & Yes & Yes & Yes & Yes \\
\hline$N$ & 43,212 & 43,212 & 43,212 & 43,212 & 43,212 & 43,212 \\
\hline$R^{2}(\%)$ & 74.10 & 73.62 & 74.06 & 73.63 & 74.06 & 73.62 \\
\hline \multicolumn{7}{|c|}{$\begin{array}{l}\text { Notes: This table reports panel regression results using fixed effect (FE) regression and generalized least squares with random effect (GLS_RE) of the } \\
\text { effect of conditional conservatism on the cost of equity capital. The } t \text { statistics in parentheses. Conservatism and Conservatism² denote conditional } \\
\text { conservatism measures CSCORE, BNEWS, and BASU_metric (as defined in Table 1) and their quadratic terms, respectively. See Table } 1 \text { for } \\
\text { other variable definitions. } * * *, * * \text {, and * represent significance levels of } 1,5 \text {, and 10\%, respectively (one-tailed test where sign is predicted; two-tailed } \\
\text { test otherwise). }\end{array}$} \\
\hline
\end{tabular}


Table 10: Conditional conservatism and the cost of equity capital: Quantile regression

\begin{tabular}{|c|c|c|c|c|c|c|c|c|c|}
\hline \multicolumn{10}{|c|}{ Panel A: Results of quantile regression model } \\
\hline \multirow{2}{*}{$\begin{array}{l}\text { Independent } \\
\text { variables }\end{array}$} & \multicolumn{9}{|c|}{ Dependent variable: COEC } \\
\hline & 10th & $20^{\text {th }}$ & 30 th & 40th & 50 th & 60 th & 70 th & 80th & 90th \\
\hline \multirow[t]{2}{*}{ Constant } & $0.458^{* * * *}$ & $0.546^{* * *}$ & $0.594^{* * *}$ & $0.653^{* * *}$ & $0.681^{* * *}$ & $0.690^{* * *}$ & $0.712^{* * *}$ & $0.706^{* * *}$ & $0.710^{* * *}$ \\
\hline & $(71.64)$ & $(66.24)$ & $(72.05)$ & $(70.77)$ & $(85.31)$ & $(62.80)$ & $(85.70)$ & $(71.47)$ & $(60.18)$ \\
\hline \multirow[t]{2}{*}{ CSCORE } & 0.057 & 0.014 & 0.002 & $-0.144^{* *}$ & $-0.293^{* * *}$ & $-0.350^{* * *}$ & $-0.536^{* * *}$ & $-0.686^{* * *}$ & $-0.754^{* * *}$ \\
\hline & $(0.80)$ & $(0.19)$ & $(0.02)$ & $(-2.06)$ & $(-3.67)$ & $(-3.99)$ & $(-5.42)$ & $(-5.85)$ & $(-6.24)$ \\
\hline \multirow[t]{2}{*}{$\mathrm{CSCORE}^{2}$} & -0.002 & 0.003 & 0.002 & $0.015^{* *}$ & $0.026^{* * *}$ & $0.032^{* * *}$ & $0.048^{* * *}$ & $0.057^{* * *}$ & $0.060^{* * *}$ \\
\hline & $(-0.37)$ & $(0.54)$ & $(0.28)$ & $(2.48)$ & (4.09) & (4.42) & (6.25) & $(5.90)$ & $(5.84)$ \\
\hline \multirow[t]{2}{*}{ SIZE } & $-0.002^{* * *}$ & $-0.003^{* * *}$ & $-0.004^{* * *}$ & $-0.004^{* * *}$ & $-0.005^{* * *}$ & $-0.005^{* * *}$ & $-0.005^{* * *}$ & $-0.005^{* * *}$ & $-0.005^{* * *}$ \\
\hline & $(-4.34)$ & $(-8.05)$ & $(-14.32)$ & $(-13.24)$ & $(-10.09)$ & $(-8.02)$ & $(-9.02)$ & $(-8.28)$ & $(-6.98)$ \\
\hline \multirow[t]{2}{*}{ МТB } & 0.000 & $0.001^{* *}$ & $0.001^{* * *}$ & $0.002^{* * *}$ & $0.002^{* * *}$ & $0.003^{* * *}$ & $0.002^{* * *}$ & $0.003^{* * *}$ & $0.004^{* * * *}$ \\
\hline & $(1.54)$ & (2.06) & $(2.84)$ & (3.68) & (3.71) & (4.18) & (3.74) & (4.29) & (4.82) \\
\hline \multirow[t]{2}{*}{ LEV } & $0.020^{* * *}$ & $0.021^{* * *}$ & $0.015^{* * *}$ & $0.010^{* * *}$ & 0.003 & 0.000 & -0.002 & $-0.014^{* * *}$ & $-0.014^{* * *}$ \\
\hline & $(9.30)$ & (7.19) & $(4.75)$ & (3.31) & (1.16) & $(0.09)$ & $(-0.67)$ & $(-3.77)$ & $(-2.64)$ \\
\hline \multirow[t]{2}{*}{ EARVOL } & $0.036^{* * *}$ & $0.038^{* * *}$ & $0.035^{* * *}$ & $0.036^{* * *}$ & $0.033^{* * *}$ & $0.024^{* * *}$ & $0.017^{* * *}$ & 0.007 & 0.004 \\
\hline & (9.66) & (9.81) & $(8.25)$ & (7.58) & (7.02) & (4.39) & (3.83) & (1.29) & $(0.92)$ \\
\hline \multirow[t]{2}{*}{ ROA } & $-0.096^{* * *}$ & $-0.114^{* * *}$ & $-0.118^{* * *}$ & $-0.126^{* * *}$ & $-0.125^{* * *}$ & $-0.135^{* * *}$ & $-0.134^{* * *}$ & $-0.147^{* * *}$ & $-0.154^{* * *}$ \\
\hline & $(-15.06)$ & $(-12.79)$ & $(-11.79)$ & $(-14.57)$ & $(-12.84)$ & $(-12.23)$ & $(-15.40)$ & $(-9.41)$ & $(-10.67)$ \\
\hline \multirow[t]{2}{*}{ RTVOL } & $0.162^{* * *}$ & $0.251^{* * *}$ & $0.370^{* * *}$ & $0.530^{* * *}$ & $0.691^{* * *}$ & $0.882^{* * *}$ & $1.095^{* * *}$ & $1.452^{* * *}$ & $1.709^{* * *}$ \\
\hline & $(23.01)$ & $(25.88)$ & $(26.45)$ & $(26.14)$ & (36.32) & $(33.52)$ & $(82.41)$ & $(51.73)$ & $(120.51)$ \\
\hline \multirow[t]{2}{*}{ GDPG } & $0.195^{* * *}$ & $0.137^{* * *}$ & $0.084^{* * * *}$ & 0.029 & $-0.060^{* * * *}$ & $-0.131^{* * * *}$ & $-0.191^{* * * *}$ & $-0.277^{* * * *}$ & $-0.312^{* * * *}$ \\
\hline & (13.02) & $(8.70)$ & (4.63) & $(1.61)$ & $(-3.09)$ & $(-6.35)$ & $(-7.00)$ & $(-12.92)$ & $(-12.85)$ \\
\hline \multirow[t]{2}{*}{ INFLATION } & $0.075^{* * *}$ & $0.129^{* * *}$ & $0.131^{* * *}$ & $0.148^{* * *}$ & $0.161^{* * *}$ & $0.152^{* * *}$ & $0.152^{* * *}$ & $0.118^{* * *}$ & 0.048 \\
\hline & (4.77) & $(6.80)$ & $(8.20)$ & (8.64) & (7.49) & (7.14) & $(7.13)$ & $(5.03)$ & $(1.91)$ \\
\hline \multirow[t]{2}{*}{ INVESPROT } & $-0.006^{* * *}$ & $-0.007^{* * *}$ & $-0.006^{* * *}$ & $-0.005^{* * *}$ & $-0.004^{* * *}$ & $-0.003^{* * *}$ & $-0.001^{*}$ & 0.001 & $0.002^{* *}$ \\
\hline & $(-13.63)$ & $(-13.48)$ & $(-9.55)$ & $(-9.53)$ & $(-7.33)$ & $(-6.85)$ & $(-2.56)$ & (1.13) & $(2.45)$ \\
\hline \multirow[t]{2}{*}{ AUDIT } & $-0.004^{* * * *}$ & $-0.002^{* *}$ & 0.000 & 0.001 & 0.002 & 0.001 & -0.001 & $-0.004^{* * * *}$ & $-0.004^{* * * *}$ \\
\hline & $(-5.16)$ & $(-2.24)$ & $(0.36)$ & $(1.00)$ & $(1.48)$ & $(1.04)$ & $(-1.16)$ & $(-2.68)$ & $(-3.20)$ \\
\hline Country dummies & Yes & Yes & Yes & Yes & Yes & Yes & Yes & Yes & Yes \\
\hline Industry dummies & Yes & Yes & Yes & Yes & Yes & Yes & Yes & Yes & Yes \\
\hline Year dummies & Yes & Yes & Yes & Yes & Yes & Yes & Yes & Yes & Yes \\
\hline Pseudo $R^{2}(\%)$ & 43.34 & 50.85 & 52.36 & 52.24 & 52.91 & 54.08 & 55.82 & 57.98 & 60.59 \\
\hline
\end{tabular}


Table 10 (continued)

Panel B: Tests of the equality of slope estimates across various quantiles

\begin{tabular}{|c|c|c|c|c|c|c|c|c|c|c|c|c|c|c|c|c|}
\hline Quantiles & \multicolumn{2}{|c|}{$\mathrm{Q}=20 \%$} & \multicolumn{2}{|c|}{$\mathrm{Q}=30 \%$} & \multicolumn{2}{|c|}{$\mathrm{Q}=40 \%$} & \multicolumn{2}{|c|}{$\mathrm{Q}=50 \%$} & \multicolumn{2}{|c|}{$\mathrm{Q}=60 \%$} & \multicolumn{2}{|c|}{$\mathrm{Q}=70 \%$} & \multicolumn{2}{|c|}{$\mathrm{Q}=80 \%$} & \multicolumn{2}{|c|}{$\mathrm{Q}=90 \%$} \\
\hline \multicolumn{17}{|c|}{ Linear term: CSCORE } \\
\hline Quantile & F. stat. & $p$-value & F. stat. & $p$-value & F. stat. & $p$-value & F. stat. & $p$-value & F. stat. & $p$-value & F. stat. & $p$-value & F. stat. & $p$-value & F. stat. & $p$-value \\
\hline $\mathrm{Q}=10 \%$ & 0.80 & $(0.371)$ & 1.33 & $(0.248)$ & $29.66 * * *$ & $(0.000)$ & $29.66^{* * *}$ & $(0.000)$ & $46.56^{* * * *}$ & $(0.000)$ & $43.10^{* * *}$ & $(0.000)$ & $43.39^{* * *}$ & $(0.000)$ & $48.79^{* * *}$ & $(0.000)$ \\
\hline$Q=20 \%$ & & & 0.11 & $(0.736)$ & $14.04^{* * *}$ & $(0.000)$ & $39.21^{* * *}$ & $(0.000)$ & $28.50^{* * * *}$ & $(0.000)$ & $38.15^{* * *}$ & $(0.000)$ & $37.48^{* * *}$ & $(0.000)$ & $41.85^{* * *}$ & $(0.000)$ \\
\hline $\mathrm{Q}=30 \%$ & & & & & $14.72^{* * *}$ & $(0.000)$ & $22.58^{* * *}$ & $(0.000)$ & $18.19^{* * * *}$ & $(0.000)$ & $26.25^{* * *}$ & $(0.000)$ & $30.01^{* * *}$ & $(0.000)$ & $33.35^{* * *}$ & $(0.000)$ \\
\hline $\mathrm{Q}=40 \%$ & & & & & & & $8.11^{* * * *}$ & $(0.004)$ & $8.44^{* * * *}$ & $(0.000)$ & $21.28^{* * *}$ & $(0.000)$ & $27.75^{\text {**** }}$ & $(0.000)$ & $25.05^{* * *}$ & $(0.000)$ \\
\hline $\mathrm{Q}=50 \%$ & & & & & & & & & 1.08 & $(0.299)$ & $10.00^{* * *}$ & $(0.001)$ & $15.75^{\text {*** }}$ & $(0.000)$ & $15.96^{* * *}$ & $(0.000)$ \\
\hline $\mathrm{Q}=60 \%$ & & & & & & & & & & & $10.00^{* * *}$ & $(0.001)$ & $12.22^{* * * *}$ & $(0.000)$ & $12.99^{* * *}$ & $(0.000)$ \\
\hline $\mathrm{Q}=70 \%$ & & & & & & & & & & & & & $6.25^{* *}$ & $(0.012)$ & $5.52^{* *}$ & $(0.018)$ \\
\hline $\mathrm{Q}=80 \%$ & & & & & & & & & & & & & & & 0.41 & $(0.523)$ \\
\hline \multicolumn{17}{|c|}{ Quadratic term: CSCORE ${ }^{2}$} \\
\hline $\mathrm{Q}=10 \%$ & 1.88 & $(0.170)$ & 0.82 & $(0.365)$ & $12.62^{* * * *}$ & $(0.000)$ & $30.49^{* * *}$ & $(0000)$ & $52.28^{* * * *}$ & $(0.000)$ & $47.67^{* * *}$ & $(0.000)$ & $40.49^{* * *}$ & $(0.000)$ & $44.76^{* * *}$ & $(0.000)$ \\
\hline$Q=20 \%$ & & & 0.24 & $(0.621)$ & $10.92^{* * *}$ & $(0.001)$ & $42.66^{* * *}$ & $(0.000)$ & $31.35^{\text {**** }}$ & $(0.000)$ & $38.91^{* * * *}$ & $(0.000)$ & $33.03^{* * * *}$ & $(0.000)$ & $38.90^{* * *}$ & $(0.000)$ \\
\hline $\mathrm{Q}=30 \%$ & & & & & $20.60^{* * *}$ & $(0.000)$ & $25.86^{* * *}$ & $(0.000)$ & $23.33^{* * *}$ & $(0.000)$ & $29.45^{* * *}$ & $(0.000)$ & $27.44^{* * *}$ & $(0.000)$ & $27.95^{* * *}$ & $(0.000)$ \\
\hline $\mathrm{Q}=40 \%$ & & & & & & & $7.45^{* * *}$ & $(0.006)$ & $9.05^{* * * *}$ & $(0.002)$ & $21.18^{* * * *}$ & $(0.000)$ & $22.53^{* * *}$ & $(0.000)$ & $18.92^{* * *}$ & $(0.322)$ \\
\hline$Q=50 \%$ & & & & & & & & & 1.45 & $(0.228)$ & $11.22^{* * * *}$ & $(0.000)$ & $14.58^{* * *}$ & $(0.000)$ & $13.86^{* * *}$ & $(0.000)$ \\
\hline $\mathrm{Q}=60 \%$ & & & & & & & & & & & $9.00^{* * * *}$ & $(0.002)$ & $8.41^{* * * *}$ & $(0.003)$ & $8.52^{* * * *}$ & $(0.003$ \\
\hline $\mathrm{Q}=70 \%$ & & & & & & & & & & & & & $3.08^{*}$ & $(0.079)$ & 2.38 & $(0.122)$ \\
\hline $\mathrm{Q}=80 \%$ & & & & & & & & & & & & & & & 0.11 & $(0.734)$ \\
\hline
\end{tabular}

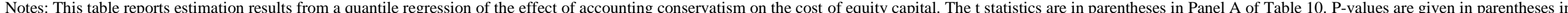

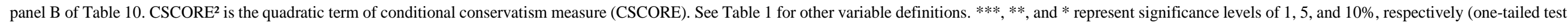
where sign is predicted; two-tailed test otherwise). 
Table 11: Conditional conservatism and the cost of equity capital: Piecewise regression

\begin{tabular}{|c|c|c|}
\hline \multirow{2}{*}{ Independent variables } & \multicolumn{2}{|c|}{ Dependent variable: COEC } \\
\hline & Coefficient & t-statistic \\
\hline Constant & $0.885^{* * *}$ & $(12.83)$ \\
\hline CSCORE_MEDIAN & $-1.009^{* * *}$ & $(-2.66)$ \\
\hline CSCORE_(MEDIAN-Q3) & $0.209^{* *}$ & $(2.09)$ \\
\hline CSCORE (Q3) & $-1.845^{* *}$ & $(-2.44)$ \\
\hline SIZE & $-0.015^{* * *}$ & $(-8.31)$ \\
\hline MTB & $0.014^{* *}$ & $(2.37)$ \\
\hline LEV & -0.021 & $(-0.62)$ \\
\hline EARVOL & $0.027^{* *}$ & $(2.33)$ \\
\hline ROA & $-0.346^{* * *}$ & $(-3.85)$ \\
\hline RTVOL & $0.858^{* * *}$ & $(9.52)$ \\
\hline GDPG & -0.367 & $(-1.08)$ \\
\hline INFLATION & 0.091 & $(0.67)$ \\
\hline INVESPROT & -0.004 & $(-0.24)$ \\
\hline AUDIT & -0.012 & $(-1.05)$ \\
\hline Industry fixed effects & \multicolumn{2}{|c|}{ Yes } \\
\hline Country fixed effects & \multicolumn{2}{|c|}{ Yes } \\
\hline Year dummies & \multicolumn{2}{|c|}{ Yes } \\
\hline$N$ & \multicolumn{2}{|c|}{43,212} \\
\hline$R^{2}(\%)$ & \multicolumn{2}{|c|}{19.80} \\
\hline \multicolumn{3}{|c|}{ 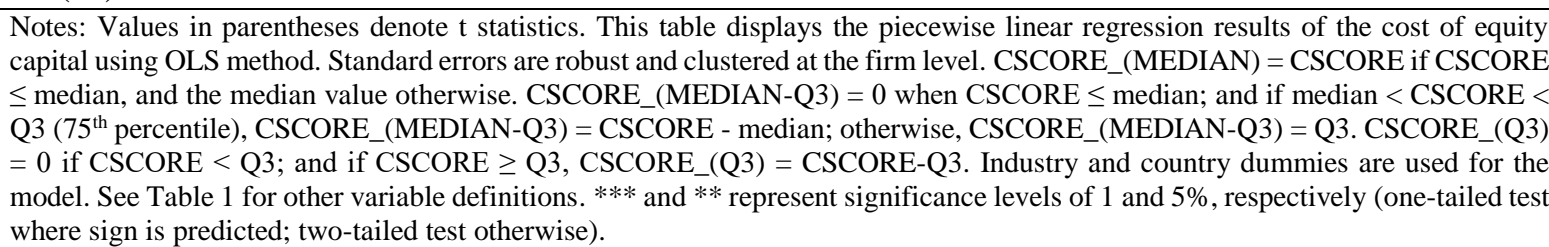 } \\
\hline
\end{tabular}


Table 12: OLS analyses of the association between conditional conservatism and the cost of equity capital by sub-period

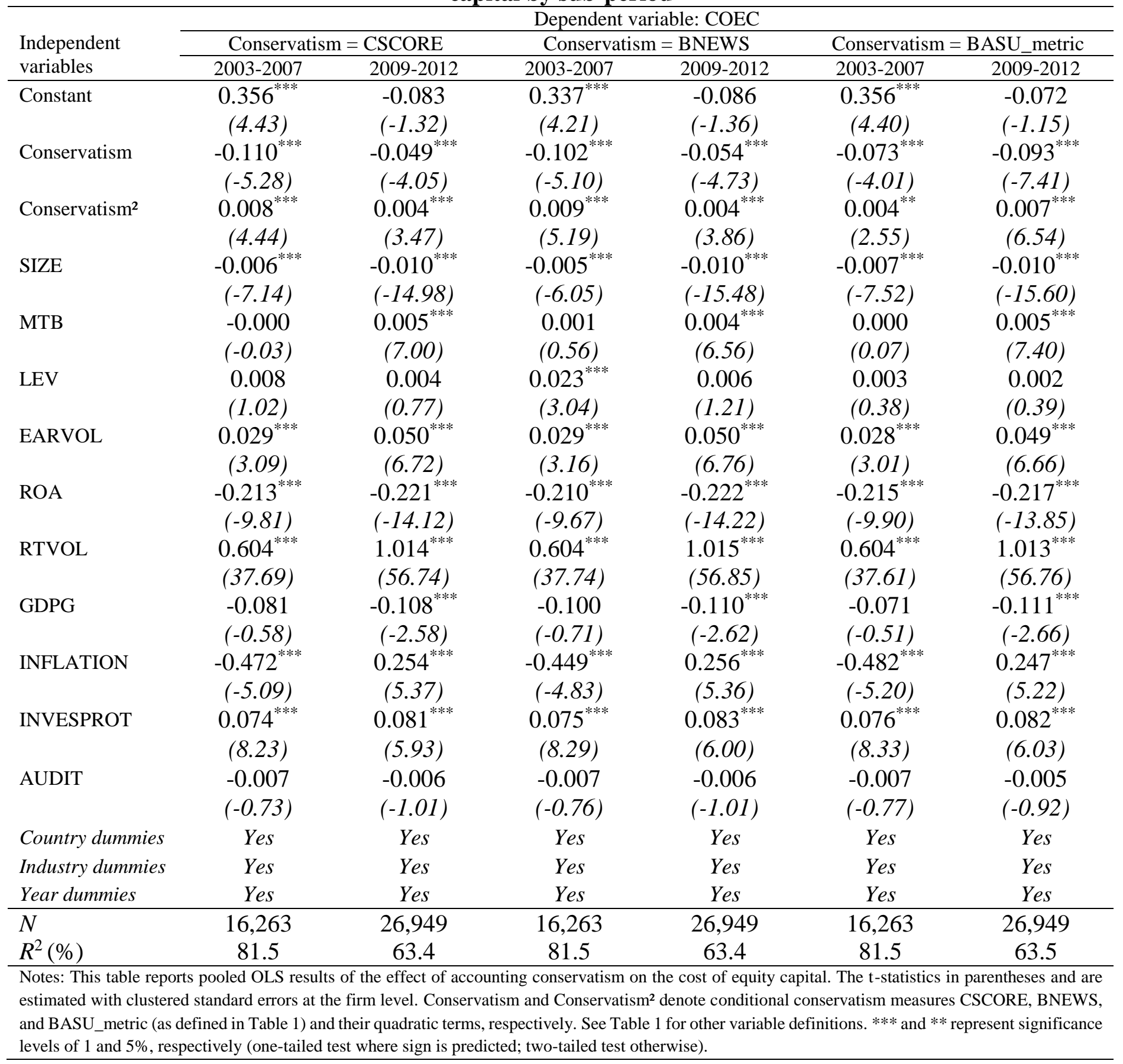


Table 13: Accounting conservatism and the cost of equity capital: Result from unequally spaced panel data regression

\begin{tabular}{|c|c|c|c|}
\hline \multirow{2}{*}{ Independent variables } & \multicolumn{3}{|c|}{ Dependent variable: COEC } \\
\hline & Conservatism $=$ CSCORE & Conservatism $=$ BNEWS & Conservatism = BASU_metric \\
\hline \multirow[t]{2}{*}{ Constant } & $0.460^{* * *}$ & $0.466^{* * *}$ & $0.459^{* * *}$ \\
\hline & $(17.46)$ & $(17.69)$ & $(17.45)$ \\
\hline \multirow[t]{2}{*}{ Conservatism } & $-0.300^{* * * *}$ & $-0.413^{* * *}$ & $-0.293^{* * *}$ \\
\hline & $(-3.40)$ & $(-4.47)$ & $(-3.31)$ \\
\hline \multirow[t]{2}{*}{ Conservatism² } & $0.021^{* * *}$ & $0.027^{* * *}$ & $0.020^{* *}$ \\
\hline & $(2.72)$ & (3.37) & $(2.63)$ \\
\hline \multirow[t]{2}{*}{ SIZE } & $-0.007^{* * *}$ & $-0.007^{* * *}$ & $-0.007^{* * *}$ \\
\hline & $(-11.77)$ & $(-11.89)$ & $(-11.77)$ \\
\hline \multirow[t]{2}{*}{ MTB } & $0.002^{* * *}$ & $0.001^{*}$ & $0.002^{* * *}$ \\
\hline & $(2.79)$ & $(1.68)$ & $(2.80)$ \\
\hline \multirow[t]{2}{*}{ LEV } & 0.007 & $0.008^{*}$ & 0.007 \\
\hline & $(1.55)$ & $(1.72)$ & $(1.56)$ \\
\hline \multirow[t]{2}{*}{ EARVOL } & $0.036^{* * *}$ & $0.036^{* * *}$ & $0.036^{* * *}$ \\
\hline & $(5.04)$ & $(5.07)$ & $(5.04)$ \\
\hline \multirow[t]{2}{*}{ ROA } & $-0.172^{* * *}$ & $-0.172^{* * *}$ & $-0.173^{* * *}$ \\
\hline & $(-11.90)$ & $(-11.90)$ & $(-11.91)$ \\
\hline \multirow[t]{2}{*}{ RTVOL } & $0.963^{* * *}$ & $0.963^{* * *}$ & $0.963^{* * *}$ \\
\hline & $(83.57)$ & $(83.51)$ & $(83.57)$ \\
\hline \multirow[t]{2}{*}{ GDPG } & $-0.192^{* * *}$ & $-0.189^{* * *}$ & $-0.192^{* * *}$ \\
\hline & $(-5.64)$ & $(-5.56)$ & $(-5.64)$ \\
\hline \multirow[t]{2}{*}{ INFLATION } & 0.030 & 0.024 & 0.031 \\
\hline & $(0.94)$ & $(0.73)$ & $(0.94)$ \\
\hline \multirow[t]{2}{*}{ INVESPROT } & 0.004 & 0.004 & 0.004 \\
\hline & (1.30) & $(1.35)$ & $(1.30)$ \\
\hline \multirow[t]{2}{*}{ AUDIT } & $-0.006^{* *}$ & $-0.006^{* *}$ & $-0.006^{* *}$ \\
\hline & $(-2.26)$ & $(-2.41)$ & $(-2.26)$ \\
\hline Country dummies & Yes & Yes & Yes \\
\hline Industry dummies & Yes & Yes & Yes \\
\hline Year dummies & Yes & Yes & Yes \\
\hline$N$ & 43,212 & 43,212 & 43,212 \\
\hline
\end{tabular}

